\title{
Revisions of Australian ground-hunting spiders. V. A new lycosoid genus from eastern Australia (Araneae: Tengellidae)
}

\author{
ROBERT J RAVEN \\ Queensland Museum, PO Box 3300, South Brisbane, Queensland 4101, Australia. Email: Robert.Raven@qm.qld.gov.au
}

\begin{abstract}
A new genus, Austrotengella, and six new species-A. toddae, A. hackerae, A. monteithi, A. wrighti, A. hebronae, A. plimeriare described from eastern Australia. The genus presents difficulties in its family placement; its relationships are discussed. Downslope altitudinal changes of 400 metres on elevation in the distribution of $A$. toddae contradict predicted shifts from climate change and minimally indicate, in this case at least, that temperature is clearly not the main driver of altitudinal models, which are considered to be far too simplistic.
\end{abstract}

Key words: Araneomorphae, Tengellidae, Lycosoidea, taxonomy, Australia, biodiversity, biogeography, phenology, distribution, climate change, downslope, altitudinal gradient

\section{Introduction}

Tengellid spiders are a diverse and enigmatic group of small to medium-sized spiders that have not been formally reported from Australia. Unlike Tengella, the Australian genera hunt in the litter and can easily be mistaken for wolf spiders (Lycosidae) or fishing spiders (Pisauridae). Raven and Stumkat (2005), following Griswold (1993), showed that the family does occur in Australia but that its definition and diagnosis are contentious. The greatest diversity of these spiders is in the USA (Platnick 1999; Platnick and Ubick 2001, 2005, 2008).

Among the collections of the Queensland Museum, one ecribellate group of spiders was identified variously as Pisauridae, Lycosidae, Cycloctenidae, Toxopidae or Amaurobiidae. The problem in placing these spiders is very much akin to that of placing a Liocranoides by Barrow (1940) and recounted by Platnick (1999). In the case of the Australian spiders, the three claws, notched trochanters and two recurved eye rows are those of the Pisauridae but the male palp is quite different, lacking pisaurid synapomorphies (see Griswold 1993). On checking for the retrocoxal hymen and predistal tarsal fracture (see Raven et al. 2002), which should be absent and present, respectively, in pisaurids, the opposite conditions were noted. That indicated a relationship with other lycosoids (Raven \& Stumkat 2005). The similarities (notably in the male palp of this genus) with Tengella seemed inescapable, despite the recurved back eye row and absence of a cribellum; it does, however, have a canoe-shaped tapetum and interlocking subtegular-tegular locking lobes (see Griswold 1993). Raven and Stumkat (2005) included this genus in their cladogram as "Australian tengellid" where it grouped with Bengalla Gray \& Thompson, 2001 as the sister group of the Ctenidae $s$. lat., not with Tengella, as the outgroup.

Silva (2003) examined the relationships of the Ctenidae and a number of groups including the Tengellidae. The preferred cladogram from that study defined the Ctenidae s. stricto by the position of the anterior lateral eyes (ALE) relative to the anterior median eyes (AME): the ALE are set so high on the clypeus that they are closer to the eyes of the posterior row than to the AME. However, in Amauropelma, Raven et al. (2001) showed that the otherwise ctenid-like morphology was contradicted by the normally-positioned two recurved eye rows. Silva (2003) postulated that the ctenoid condition, including that in Amauropelma, was diagnosed by a broad epigynal plate, often with lateral teeth. The Ctenidae s. stricto (Silva 2003) were delimited by the elevated position of the anterior lateral eyes, only otherwise seen in Cycloctenus and perhaps other cycloctenids. However, in Amauropelma, the eyes are widely and plesiomorphically not ctenoid in that sense and yet the genus fell well within the Ctenidae $s$. stricto clade close to Ctenus, thus the diagnostic eye condition of the Ctenidae is polythetic. 


\section{Material and methods}

Abbreviations are standard for the Araneae (see Raven \& Stumkat, 2005); in addition, RCH, retrocoxal hymen, a pallid unsclerotised zone retrolaterally on coxa I, introduced by Raven et al. (2002); RTA, retrolateral tibial apophysis. The tapetum was recorded in the PME. Leg measurements are given in the description as leg 1: femur, patella, tibia, metatarsus (absent in palp), tarsus, total. Spine counts on lateral and ventral surfaces are dependent on the angle of viewing; hence, absolute differences in, for example, the ventral count on metatarsi III and IV should not be taken as significant as, in some cases, a ventrolateral spine may have been scored as lateral in one case and ventral in another. Spines ventrally on tibiae I, II are described as proventral (pv) and retroventral (rv) which condition differs from the paired ventral spines normally seen in two ways First, the pro- and retroventral spines are not paired but the rows are juxtaposed and, second, viewed from the side the rows are ventral basally but for a diagonal line to be lateral distally. A male and female from the same locality were sought for holotype and female paratype (here termed allotype), respectively; however, in some cases, specimens that are in better condition and hence better represent the taxon came from other localities. Juveniles collected with adults are assumed to be conspecific but are not paratypes; they are included as an indication of activity and maturation periods. Abbreviations: NP, National Park; QM party, Queensland Museum Terrestrial Biodiversity staff. Digital photographs were taken with a Nikon Coolpix 880 or Nikon Coolpix 5400, hand-held on the eyepiece of a Zeiss Stemi SV11 stereomicroscope or Leica SZ, resolution being 3 and 5 megapixels respectively. Epigynes were drawn with a camera lucida on a Zeiss Stemi SV6. Scanning electron micrographs were done on a Hitachi S530. Museums.- QM, Queensland Museum, Brisbane; AMS, Australian Museum, Sydney.

\section{Taxonomy}

\section{Family Tengellidae Dahl 1908}

Tengellidae Dahl 1908: 194.

Diagnosis: Tengellids differ from ctenids in having a canoe-shaped tapetum and the eyes in two recurved rows but the ALE are not set high near the eyes of the posterior row. They differ from pisaurids in having a retrocoxal hymen and from lycosids in having a retrolateral tibial apophysis on the male palp.

Distribution: USA, Mexico, Madagascar, Central America, New Zealand, Australia.

\section{Austrotengella gen. nov.}

Diagnosis: Differs from Bengalla in the form of the male tibial apophysis (e.g., Figs 8b-e), the extensive epigynal scape (e.g., Fig. 2c), and from both Huntia and Bengalla in having more than 4 pairs of spines ventrally on tibiae I and II, the posterior row of eyes being recurved (Fig. 1b) and the very long paired and unpaired claws. Differs from Amauropelma in the absence of claw tufts and the presence of a third claw.

Description: Eight eyes in two rows, both rows clearly recurved from above and in front; anterior row about two-thirds width of posterior row; from front, ALE set only about half AME diameter above AME line; PME with canoe-shaped tapetum; eye group occupying 0.6 of headwidth (Fig. 1a). Three claws; claw tufts absent; paired claws similar, very long with few teeth basally; third claw long, bare. Retrocoxal hymen present on leg I only, pretarsal fracture absent. Tibiae I, II of females with 5 pairs of strong ventral spines with small distal pair; 3 pairs of strong spines ventrally on metatarsi I, II; similar number in males but weaker. General spine conformation: femora I only with 2 very strong subdistally on proventral face; femora I-IV also with spines prolaterally, dorsally and retrolaterally; patellae I, II aspinose; patellae III, IV and palp with one spine; tibiae III, IV typically p2d2r2v2.2.2, ventral spines weak; metatarsi II also with spines prolaterally, dorsally and retrolaterally; metatarsi III, IV typically p2r3v2.2.2-3, ventral spines weak; female palp typically, fe p1d2; pa p1; ti p2d1; ta p2.1d1r1 with 2 small spines ventrally just behind claw. Scopulae entirely absent on legs. Preening combs absent. Two rows of trichobothria on tibia, metatarsi and tarsi; trichobothrial bases collariform (Fig. 5d) ; trochanters all with similarly shallow notches. Male tibiae without basal fracture. Tarsal organ low, keyhole-shaped (Fig. 5d). Six spinnerets with short ALS and 
PLS and short apical segment (Fig. 1c); females with 5-6 large conical spigots dorsolaterally on PMS, largest spigots evident dorsally in two rows (A. wrighti); PMS as long as PLS but more slender, conical, cribellum absent; colulus indistinct, small, circular, sclerotised hirsute area.

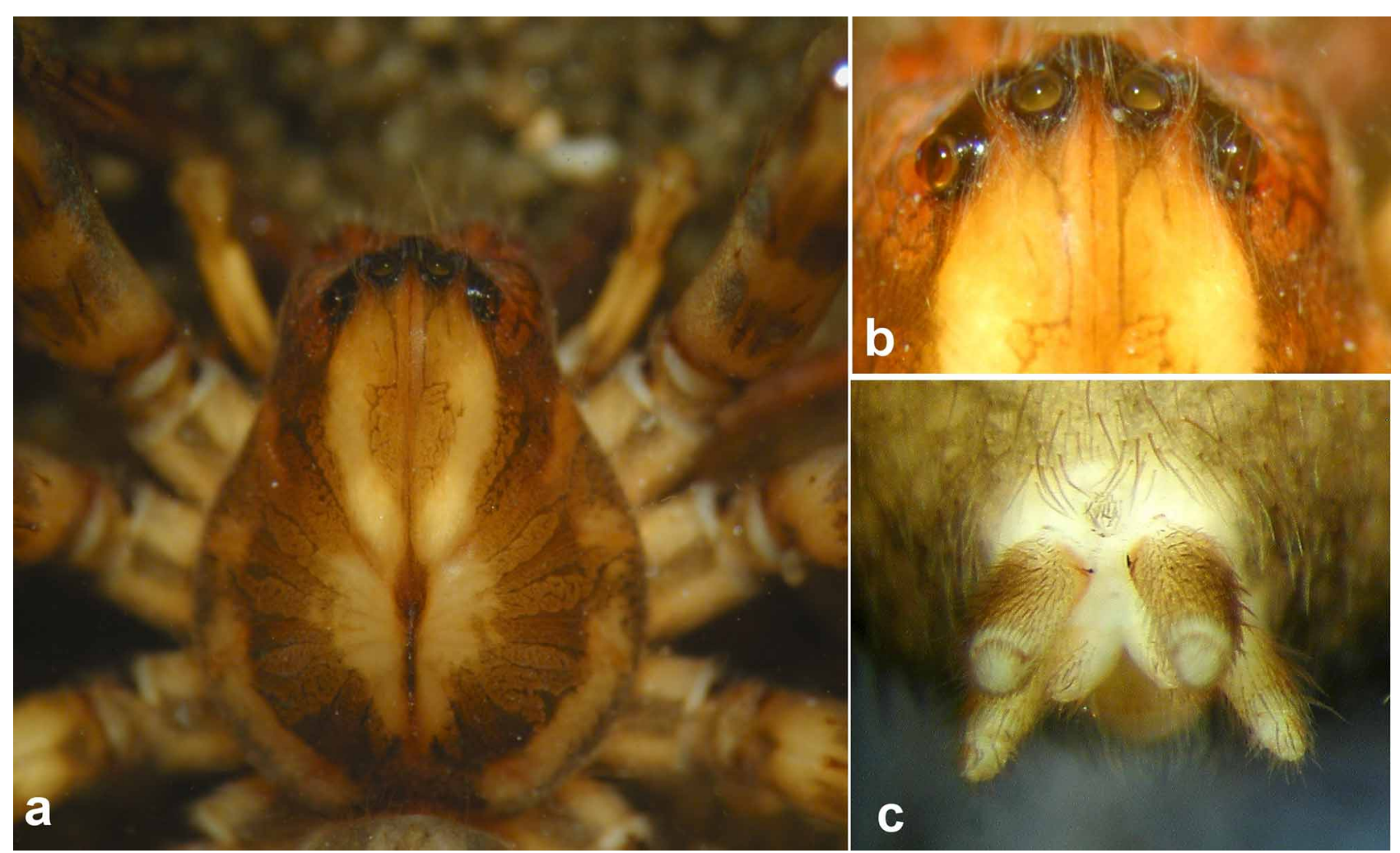

FIGURE 1. Austrotengella hackerae, sp. nov., carapace (a), eyes, dorsal view(b), spinnerets (c).

Male palp with median apophysis (Fig. 2a), broad embolus and conductor; U-shaped subtegulum; extensive tegulum; interlocking tegular-subtegular lobes present. Median apophysis shaped like blunt-ended canoe, open face upward, with distal edge twisted, folded back on itself, translucent. Conductor large, flared, hyaline. Embolus a broad process with ventral groove (Fig. 2a, 5a), which may be basally closed to open for its full length and thus evident as more pallid zone. RTA set on retrolateral to retrodorsal edges with two shallow apices, surfaces of apices lamellate (Fig. 8f); cymbium shallow, canoe-shaped with conical tip with or without dorsal process, interlocking lobes present between cymbium and distal tibia both ventrally and prolaterally (Figs. 8b, d). Scopulae absent or, rarely, weak on cymbium. Epigyne with lateral teeth, broad median plate with (Fig. 2c) or without (Fig. 13c) posterior invagination; transverse recurved ridge on septum (Fig. 2c); internally quite simple.

Females remain with eggsac, which is silked to the underside of logs or rocks, sometimes it is soil- and barkencrusted.

Type Species. Austrotengella toddae sp. nov.

Species Included: Austrotengella toddae sp. nov., Austrotengella hackerae sp. nov., Austrotengella hebronae sp. nov., Austrotengella monteithi sp. nov., Austrotengella plimeri sp. nov., Austrotengella wrighti sp. nov.

Distribution and Habitat (Fig. 3). Known only from rainforests in southeastern Queensland and northeastern New South Wales where it is common in the litter. Most species occur at elevations below 760 metres.

Significantly, A. toddae occurs only at Lamington National Park. Prior to 2006, when the only sites sampled were at elevations above 800 metres, spiders were found. However, in the IBISCA survey (2006/2007) at elevations from 300-1100 metres, adult spiders were only found at $500 \mathrm{~m}$ and 700 metres with one juvenile taken at $900 \mathrm{~m}$. This is discussed further below.

Relationships. Austrotengella is excluded from Pisauridae and other higher lycosoids (sensu Silva 2003; Raven and Stumkat 2005) by the canoe-shaped tapetum. Equally, females remain with the eggsac, which is silked to the underside of logs and rocks, and were soil- and bark-encrusted. Forster and Forster (1999: 115) reported this also for Cycloctenus. From the front, the ALE of Austrotengella are beside the AME. 


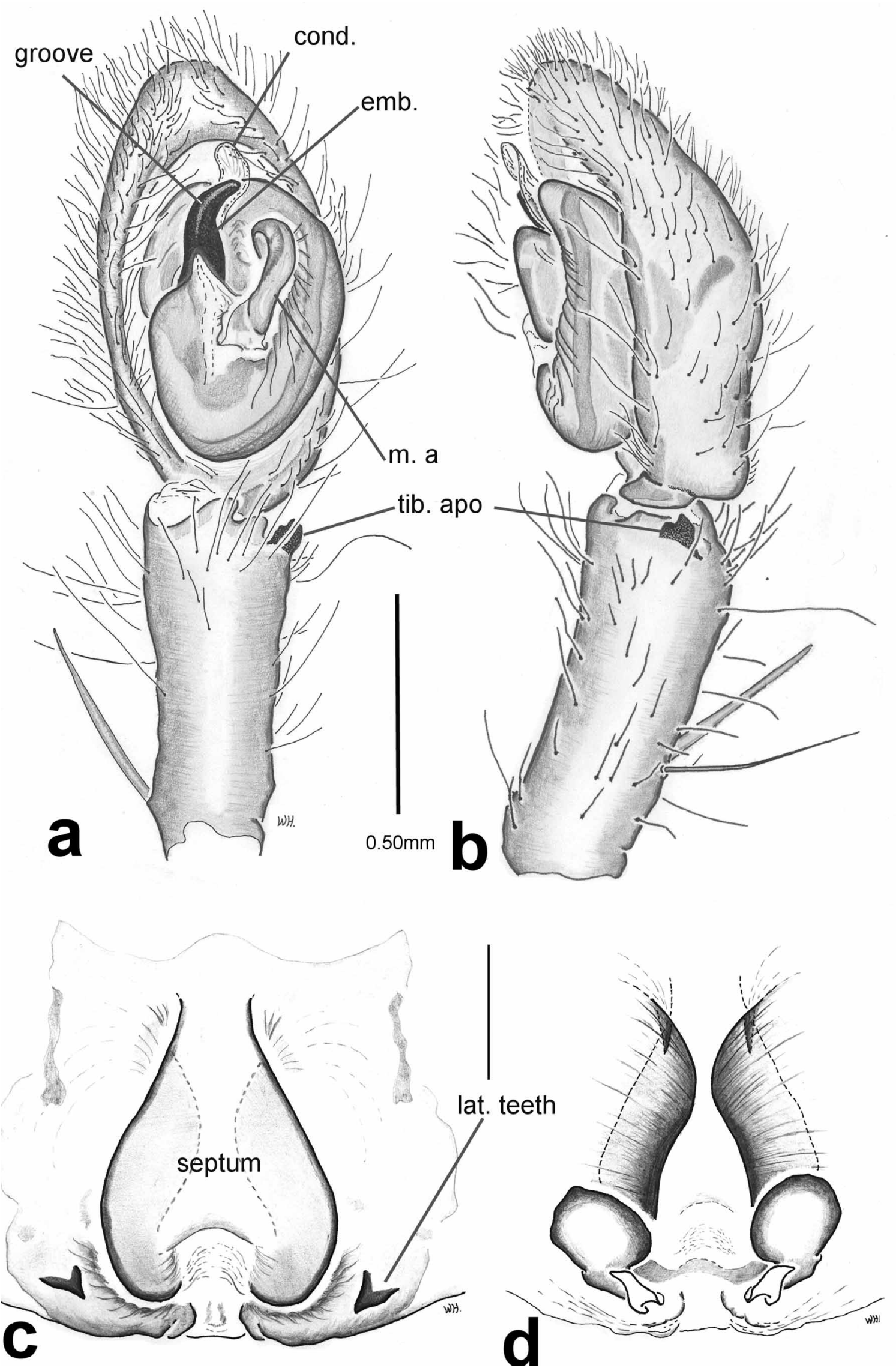

FIGURE 2. Austrotengella toddae, sp. nov., holotype male QM S76432, palpal tibia, cymbium and bulb (a, b): ventral view (a), and retrolateral view (b). Allotype, female QMS33206, epigyne (c, d): epigyne, external (c) and internal (d) views. Scale lines $0.5 \mathrm{~mm}$ for $\mathrm{a}, \mathrm{b}, 0.25 \mathrm{~mm}$ for $\mathrm{c}, \mathrm{d}$. 
Remarks: Interspecific differences in somatic characters in this genus are diffuse; hence, species are diagnosed exclusively on the genitalia. Closely related species may be more readily diagnosed by the female epigyne than the male palp. Differences between closely related species are small and difficult to unambiguously describe but they are consistent.

\section{Ecological biogeography}

Cursorial invertebrate sampling in Queensland (Fig. 3).

In any biogeographic analysis, the exhaustiveness of surveys is critical. Undersampling may lead to spurious conclusions. Sampling of ground-hunting spiders has been quite extensive in southeastern Queensland since the early 1970s.

Geoff Monteith, then of the University of Queensland, initiated an extensive pitfall trapping survey of over 100 rainforest sites at different elevations from 1974-1976. Two bucket traps, each protected by a rain shield, were set at each site for up to 3 months, cleared and then reset over about 14 months. The spiders were donated to the Queensland Museum. This survey presents a very important starting point to our understanding of the faunas, their taxonomy and biogeography and even the sustainability of forest management.

Soon after Monteith's self-funded survey, the newly formed Australian Biological Resources Study (ABRS) funded invertebrate and vertebrate expeditions (by Dr Valerie Davies, Jeanette Covacevich, along with RJR and other QM staff, and that of the Australian Museum) of forests in Cape York (Iron Range), northeastern Queensland (Mt Molloy to Cooktown), mideastern Queensland (from Eungella National Park to Bulburin State Forest, near Gladstone), and southeastern Queensland (Bunya Mountains National Park, east to Cooloola National Park and south to Lamington National Park) (Davies 1977). Subsequently, Valerie Davies, QM Curator of Arachnids from 1969-1985, initiated arachnid surveys of forests at Brookfield and Rochedale, near Brisbane. Ms Maureen Glover, QM Volunteer, conducted intensive surveys of heathland around the Beerwah area, just north of Brisbane. More recently, the QM, with the support and cooperation of the Brisbane City Council and Redlands Shire Council, surveyed the invertebrates of the Greater Brisbane area from Boombana National Park, near Mt Nebo east to the Boondal Wetlands and south to Karawatha, Logan Shire, and east to Redlands Shire.

Lamington National Park: Finally, in 2006/2007, a major altitudinal survey of invertebrates was conducted at Lamington National Park on a ridge leading to the western edge of the park (near O'Reilly's Guesthouse). The IBISCA-BATH (Biodiversity at the Heights) project (Kitching et al. 2011, Strong et al. 2011) at Lamington National Park was set in subtropical rainforests that rises continuously from elevations of 300 to 1100 metres on ridges formed on the northern edge of the Mt Warning caldera. Lamington National Park is the oldest national park in Queensland and has been well managed. Sampling was rigorously repeated with 4 sites at each of 5 elevations (roughly 300, 500, 700, 900 and 1100 metres). Although the most intense sampling was in summer, a later smaller survey at the same sites was also conducted in winter. Methods that would sample ground spiders were hand sampling, litter, pitfall trap and malaise traps.

The result of these intensive surveys is that not only do we know where many arachnid species do occur, we can also hypothesise with abundant data that we know where those species do not occur in southeastern Queensland (Fig. 3). That data set enables a very strong understanding of biogeography in the region.

Austrotengella. Species of the genus Austrotengella are mostly known from lowland (elevations up to 700 metres) rainforest and other closed forests in southeastern Queensland, from just west of Gympie to near Kempsey, northern New South Wales (Fig. 3). Only one species, A. toddae, has been found above these elevations. In all of these areas, specimens have usually been taken by brief hand collections from under logs and rocks, or by shortterm pitfall trapping.

Many populations of most of these Austrotengella species, but especially A. hackerae, are now effectively isolated in their rainforest area by the clearing of surrounding rainforest for pasture or urban development. In some cases, the size of the forest in which these species are now found is quite small, e.g., "Buhot" is no longer rainforest and the area of moist forest in 2004 was less than 100 metres x 100 metres. This may in part explain the intraspecific variation between populations; they are already geographically if not also reproductively isolated. Austrotengella are closed forest spiders and not known to aerially disperse. 


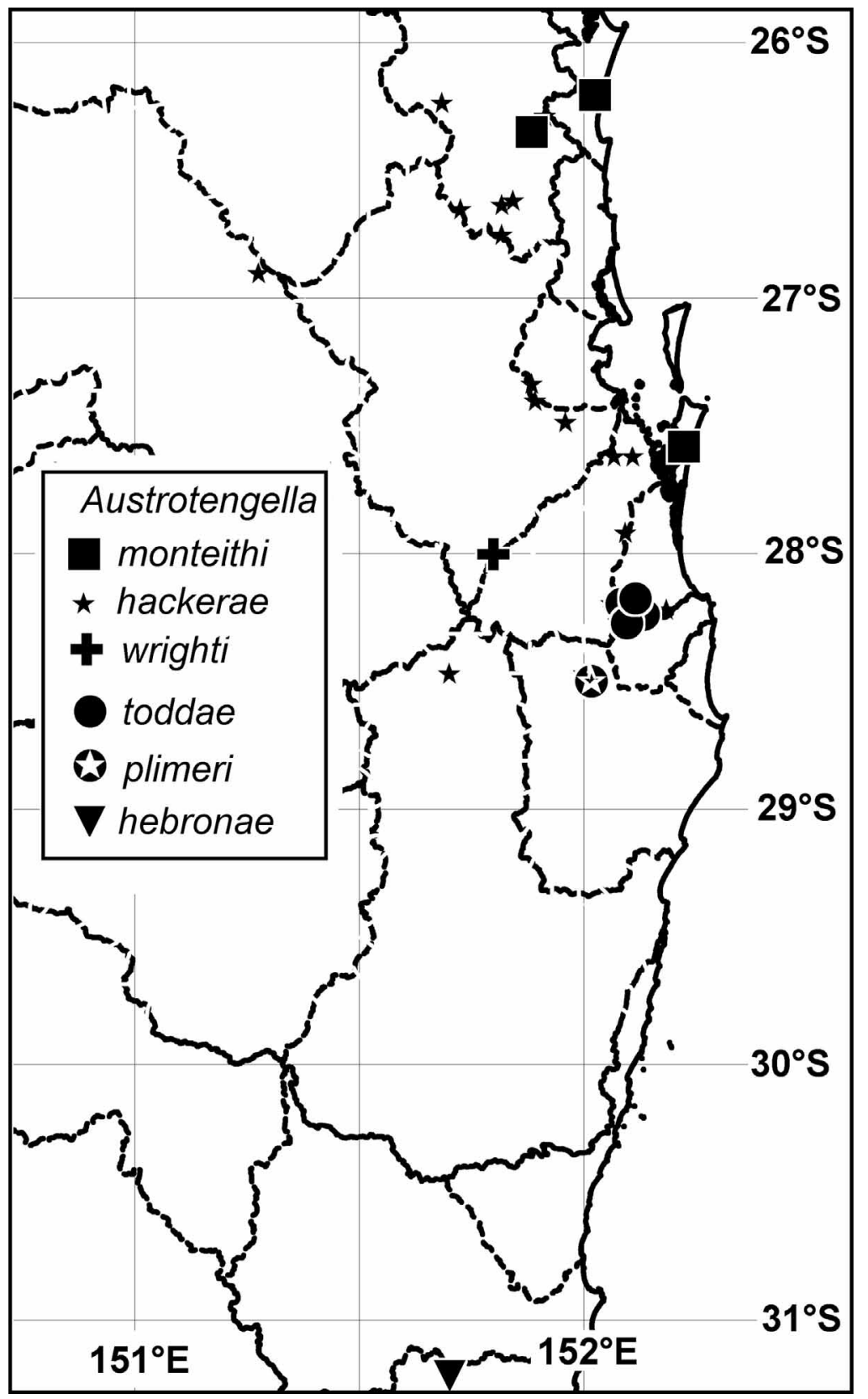

FIGURE 3. Eastern Australia showing records of Austrotengella.

The distributions of some species in southeastern Queensland follow a pattern not yet seen in spiders (Fig. 3). For example, A. monteithi occurs in montane rainforests on the Cooran Plateau (Fig. 3) as well as lowland rainforest on sand surrounded by heath in coastal Cooloola and on North Stradbroke Island. Austrotengella monteithi is readily distinguished from the geographically close $A$. hackerae, which occurs from lowland rainforest at Brookfield and Gold Creek onto the D'Aigular Range south to Ravensbourne National Park and north to near Cooran.

Austrotengella toddae. The full extent of the distribution of A. toddae is not clear but it is certainly found on the Lamington Plateau on the northern edge of the Mt Warning caldera. Further south and west on that caldera, the nearest species geographically, A. plimeri, provides a reference point. Despite their close geographic proximity, $A$. toddae and A. plimeri are morphologically more different than any other two species, except perhaps for $A$. wrighti and $A$. toddae.

The IBISCA Hypothesis. One of the goals of the IBISCA project was to identify faunal elements that could serve as climate change indicators. The expected change in the case of warming, all other issues (e.g., competition with other litter spiders) aside, is that over time the spiders should start being taken at higher ele- 
vations and cease to be taken at lower elevations. This is predicted by the richly supported hypothesis (e.g., Chen et al. 2009) that high altitude (rainforest) species are thermally specialised (e.g., Jansen 1967). Setting aside the causal process of any warming, concerns are held for the survival of fauna and flora whose distributions are substantially defined by parameters of humidity and temperature (e.g., Jansen 1967), which has been presumed to be true of much of the montane fauna. Certainly, humidity and temperature do change along altitudinal gradients, as has been documented at Lamington National Park (Strong et al. 2011, Kitching et al. 2011). Hence, the prediction about the effect of increasing (global) temperatures on fauna so bounded as they will gradually move further up mountains following the optimal temperature (and humidity) gradient (see Chen et al. 2009).

Tarlina woodwardi. Initially, the most suitable spider species to monitor temperature related changes seemed to be the gradungulid Tarlina woodwardi (Forster, 1955). Even as juveniles, Tarlina are readily recognised by the highly dimorphic "paired" claws on the legs; hence confusion in identifications is less likely. In most spiders, these claws are twins, of similar size and sometimes mirrored dentition. In Tarlina, one of the two claws is greatly elongated (Forster 1955, fig. 2a). Tarlina woodwardi were known only from leaf litter at elevations between 900 and 1100 metres. That, however, reflected a sampling bias: little invertebrate collecting was done in Lamington National Park below those elevations (Queensland Museum Records).

During the IBISCA study, using intensive and standardised sampling, Tarlina juveniles were found at elevations of 300-900 metres, whereas adults were found only rarely at 630 metres and commonly at 900-1100 metres. It could be argued that the Tarlina, being juveniles, were dispersed to the lower elevation by heavy rain causing flooding in the litter and would not necessarily survive at the lower elevations. Indeed, no adult Tarlina were taken in the standardised sampling or other sampling at 630 metres or lower. Hence, the lower occurrence of Tarlina should be considered as a result of dispersions. Platnick (1976) succinctly summarised the difference between movement of individuals (dispersion) and expansion of a species range (dispersal). Although juveniles could be considered to aerially disperse, there is no evidence to support that in gradungulids and only the presence of breeding adults at a point should be taken as indication of successful colonisation. So as far as Tarlina woodwardi is concerned, the elevation in which the spider had been taken prior to 2006 was the same as that in 2006/2007; no change in elevation was apparent.

In the preparation of this manuscript, I recognised that a second species would also be useful monitor. To a lesser extent than Tarlina woodwardi, both adults and juveniles of Austrotengella toddae are also quite distinctive in collections from Lamington National Park. However, in life at lower elevations, juveniles of A. toddae may be confused with the zorid, Hestimodema. Both Tarlina and Austrotengella can be found by targeted collecting under logs and rocks.

Austrotengella toddae. Given the thoroughness of the IBISCA-BATH study at Lamington Plateau, the distribution of the species should be well understood; absences should be real In that survey, adults of Austrotengella toddae were taken only at elevations of 500-700 metres with the exception of one subadult taken at 900 metres. Several hundred samples each containing 1-120 specimens were examined. Most samples were taken in summer (February) with a smaller set taken in 2007 in July.

Prior to 1985, all sampling at Lamington National Park had been only at 900 metres or higher. Adults of $A$. toddae were taken at 900 metres were taken in winter (July, 1973) and at Mt Bithongabel (1100 metres) between January and April 1976. The spiders taken between 30 and 39 years ago at Lamington National Park were 400 metres higher than in 2006/2007.

Two possibilities emerge in this case: A. toddae was widespread in altitudes from 500-1100m but only in the IBISCA project did the spiders at lower elevations get sampled; or the spiders have 200 metre altitudinal range and have moved down the mountain since 1976. Records of the other species suggest that the spiders do have a limited altitudinal range so the latter option is more likely. What then has caused the spiders to move to lower elevations?

Seasonal phenology may be thought to explain the issue but the earliest recorded adults were taken in winter (July, 1973 at $900 \mathrm{~m}$ ), which further exaggerates the dilemma.

If climatic factors are the sole drivers of the altitudinal distribution of Austrotengella toddae, the apparent absence of the spiders at the higher elevations of Lamington National Park in 2006/2007 combined with their presence, in number, at much lower elevations than that taken in the mid-to late 1970, requires one or two scenarios. One possibility, contradicting all known evidence, is that substantial local cooling has occurred from 1973 to 2006. The other possibility is that a massive spike in temperature on Lamington occurred just before the collections in 
1973. Although records for Lamington have not been kept, Mt Tamborine (a similar but lower some 20km distant by line of sight) should serve as a surrogate and no such temperature changes have been reported for Mt Tamborine in those times (www.bom.gov.au).

In regard to the expected shift in distributions (latitudinally polar, altitudinally upward) from warming, a number of studies have shown that different animal groups (including moths and butterflies) have followed the predicted path of a warming model and moved upslope over time but many also moved downward. Equally, in other long term studies, species have been shown to move down the slope (Lenoir et al. 2010). Similarly, Poloczanska et al. (2011) reported more inshore marine species on east coastal Australia moved northward, against the predicted warming model, than southward.

Thus, the simplistic model that the spiders would be forced upward with warming is inadequate; temperature is clearly not the sole driver of the altitudinal distribution of Austrotengella toddae. Clearly, many issues remain unassessed. Not the least of these is microclimatic issues involving the complexity of habitats, depths of soil cavities, and moisture-holding plants and fungi to which spiders may retreat in times of temperature and humidity stress. Equally, if the northern and western faces of the mountain receiving the strongest sun exposure are too unsuitable for the spiders, without changing altitude the spiders may simply move to the more shaded side of the mountain. In a similar hypothesis, Harvey (2002) posited that short-range endemics (invertebrates including spiders) now only occur on the south-facing slopes including gullies within their range. The current climate models (e.g., Lenoir et al. 2010) are presently not incorporating these kinds of complexities.

In conclusion, although the data are meagre, it is clear that some of the invertebrate fauna, certainly Austrotengella toddae, will not be forced to move to higher elevations and eventually to extinction simply because the climate is warming. Apart from the Darwinian fitness of the spiders, the complexity of these forests provides ample opportunity for the fauna to conflate highly simplistic climate modelling.

\section{Key}

\section{Females}

1. Epigyne with distinct posterior invagination (Fig. 2c) or posterior transverse ridge (Fig. 6a) $\ldots \ldots \ldots \ldots \ldots \ldots \ldots$ Epigyne posteriorly truncate or with slight invagination (Fig. 13c) $\ldots \ldots \ldots \ldots \ldots \ldots \ldots \ldots \ldots \ldots \ldots \ldots \ldots \ldots \ldots$

2. Lateral teeth directed more or less transversely toward each other and just posterior to widest point on plate (Fig. 6c) .......

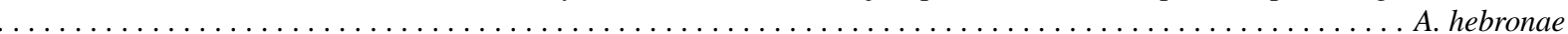

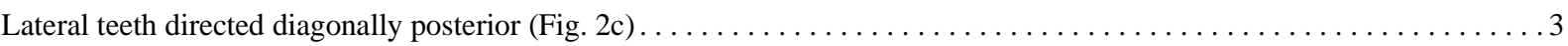

3. Lateral teeth set in line of or posterior to edge of septum; septum well defined, U-shaped (Fig. 11c) ........... plimeri Lateral teeth clearly set lateral of septum, usually closer to its widest point than its posterior margin; median ridge indistinct or

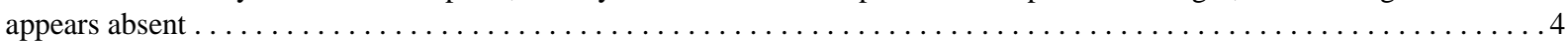

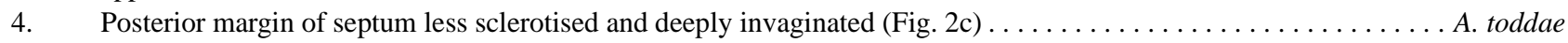

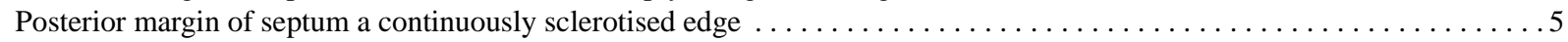

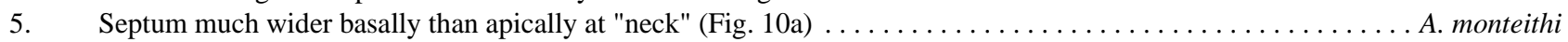

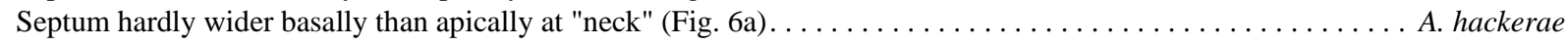

Males (males of A. hebronae are unknown)

1. Embolus and median apophysis small and longitudinal extents not or hardly overlapping (Fig. 11a)............ plimeri Embolus and median apophysis large and longitudinal extents mainly overlapping (Fig. 2a) ..................

2. Embolus sinuous, notably basally and ventral groove open for most of its length but not basally (Fig. 2a).......... toddae

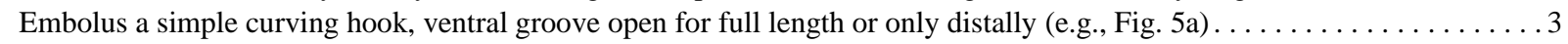

3. Retrobasal cymbium ventrally with broad flanged extension opposite RTA (Figs. 8a, 13a) . . . . . . . . . . . . 4 Narrow cymbial border retrobasally (Fig. 5c) with indistinct keel and ventral embolic groove open for full length (Figs 5a, b). Ventral groove of embolus open for full length; tip of RTA bifurcate with similar apices (Fig. 13a) . . ........ A. wrighti Ventral groove of embolus open only near tip (Fig. 8a); tip of RTA with single apex and small subdistal bump ventrally (Figs

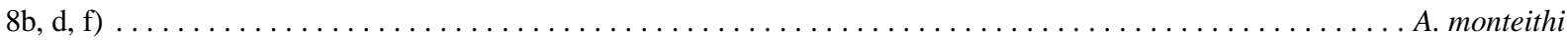


Austrotengella toddae sp. nov.

(Figs 2a-d, 3)

Diagnosis: Males differ from those of A. monteithi sp. nov. in having the ventral groove of the embolus open for most of its length but not basally; the retrobasal flange of the cymbium being narrow and rounded, the larger subdistal mound on RTA (Figs 2a, b) and relatively narrower median apophysis. Females differ in that the posterior epigynal invagination distinctly narrows posteriorly whereas in A. monteithi, it is parallel-sided.

Etymology: In honour or Dr Valerie Davies, for her much appreciated teaching in critical thinking.

Material examined: Holotype: male, Lamington National Park IBISCA (Site 500C, Sampcode 30786),474 m, dung baited pitfall, 23-28 Oct 2006, 28²1'S 153⒔9'E, R. Menendez, G. Monteith, (QM S76432).

Paratypes: allotype female, O'Reillys, Lamington National Park, 153¹0'S 2812'E, 945m, 22 Jul 1973 , R. Raven (QM S33219); male, Repeater Station, Springbrook, 28¹4'S 15316'E, SE.QLD, 1100m, rainforest, pitfall, 25 May-13 Oct 1975, G. and S. Monteith (QM S33210).

Other Material: Lamington National Park, rainforest: $28^{\circ} 12^{\prime} \mathrm{S} 153^{\circ} 10^{\prime} \mathrm{E}, 945 \mathrm{~m}$, rainforest, 1 female, $22 \mathrm{Jul}$ 1973, R.J. Raven (QM S33219); Lower Albert River (south-facing slope), 28 ${ }^{\circ} 17^{\prime} \mathrm{S} 153^{\circ} 05^{\prime} \mathrm{E}, 245 \mathrm{~m}$, pitfall, $1 \mathrm{male}$, 4 Apr-8 Sep 1976, G. and S. Monteith (QM S28838); O'Reillys, 28¹3'S 15308'E, 945m, pitfall, 1 male, 1 Oct-18 Nov 1980 (QM S18505); Mt Bithongabel, 28¹5'S 153¹0'E, 1160m, pitfall: 1 male, 31 Jan-11 Apr 1976, G. and S. Monteith (QM S28835); 1 male, IBISCA survey, site 700B, 775m, 6-9 Oct 2006, K. Staunton, B. Baehr (QM S81008). Numinbah Arch, Nerang Valley, 28 $12^{\prime} \mathrm{S} 153^{\circ} 13^{\prime} \mathrm{E}, 305 \mathrm{~m}$, rainforest, pitfall, 1 male, 26 Oct-14 Dec 1974, G. and S. Monteith (QM S30449). Same data as holotype, 1 female, 25 May-13 Oct 1975, G. and S. Monteith (QM S33206). Tomewin Range, Currumbin, 28 ${ }^{\circ} 13^{\prime} \mathrm{S} 153^{\circ} 22^{\prime} \mathrm{E}, 500 \mathrm{~m}$, pitfall, 1 male, 1989, G. Monteith, D. Cook (QM S37871). Upper Tallebudgera Valley, $28^{\circ} 14^{\prime} \mathrm{S} 153^{\circ} 16^{\prime} \mathrm{E}, 550 \mathrm{~m}$, rainforest, pitfall, 1 female, 8 Jan-17 Mar 1985, G. Monteith, G. Thompson, D. Cook (QM S72299).

Description (Holotype male QM S76432)

Carapace 3.41 long, 2.72 wide. Abdomen 2.72 long, 1.36 wide.

Colour. Carapace orange brown with wide mottled brown dusky band from PLE subcentrally to back slope; margin edged in black. Abdomen dorsally brown with bell-shaped pattern and posterior chevrons. Legs yellow brown with slightly dark femora distally. Chelicerae red-brown. Sternum, maxillae and labium yellow brown. Abdomen ventrally paler gray with white spots in band along ventrolateral edge.

Carapace. Lightly hirsute with long fine hairs on margins and uniformly in darker areas. Fovea long, ca. 0.25 carapace length. Caput arched gently, neatly demarcated; otherwise like Dolomedes, without marginal plateau.

Eyes. Eight, in two recurved rows, all of similar size but ALE smallest, PLE biggest. AME on common tubercle. Sizes of AME: ALE: PME: PLE, 10: 11: 11: 14. Interspaces (same scale as eyes): AME-AME, 8; AME-ALE, 3; PME-PME, 8; PME-PLE, 15. Ratio of front width: Back width: length, 55: 76: 45.

Chelicerae. Long fang with 3 teeth on retromargin, 2 on promargin.

Maxillae. Rectanguloid, anteriorly diagonally truncate.

Labium. Slightly longer than wide.

Sternum. broad flat shield without intercoxal extensions.

Legs. Retrocoxal hymen large, dominant; tarsi without predistal fracture; tibiae without basal fracture. All trochanters equally and distinctly notched, each notch about 2-3 times wider than deep.

Leg measurements of Austrotengella toddae, holotype male

$\begin{array}{llllll} & \text { I } & \text { II } & \text { III } & \text { IV } & \text { Palp } \\ \text { Femur } & 3.88 & 3.88 & 3.56 & 3.94 & 0.63 \\ \text { Patella } & 1.56 & 1.38 & 1.06 & 1.19 & 0.63 \\ \text { Tibia } & 3.69 & 3.50 & 2.94 & 3.44 & 0.75 \\ \text { Metatarsus } & 3.81 & 3.38 & 3.19 & 4.63 & 0.00 \\ \text { Tarsus } & 2.00 & 1.69 & 1.56 & 2.00 & 1.00 \\ \text { Total } & 14.94 & 13.81 & 12.31 & 15.19 & 3.00\end{array}$

Trichobothria. 12-15 dorsally on tarsi in band. Tarsal organ subdistal, distinctly raised; dorsal tarsi slopes down from it. 
Claws. Three; paired long, slender, with 4 long teeth distally; unpaired long, curved, bare on all legs.

Spines. I: fe pv1p3d3r3; pa 0; ti p1r1pv6rv6; me p1pv3rv3, without distal whorl. II: fe pv1p3d3r3; pa 0; ti p2d2r2v2.2.2.2.2.2; me p2r1v2.2.2. III: p3d3r4; pa p1; ti p2d2r2v2.2.2; me p3r3v2.2.4. IV: fe p4d3r2; pa p1; ti p2d2r2v2.2.2; me p3r4v2.2.4. Palp: fe p1d1.1.2r1; pa 0; ti p2d1; cymbium 0 .

Palp. Tibia elongate with low distal RTA with two low longitudinally ridges lobes; distoventral tibia two coniform processes interlocking with cymbial process. Bulb with large tegulum encircling reniform median apophysis; embolus distal, basally fused to tegulum, narrowly triangular with distal fluting; conductor small, broad, palmshaped, localised near embolus tip. Longitudinal extents of median apophysis and embolus overlap by $60 \%$.

Description (Allotype female QMS 33219)

Carapace 4.56 long, 3.69 wide. Abdomen 5.00 long, 3.13 wide.

Colour. As for male.

Carapace. As for male.

Eyes. As for male.

Chelicerae. 3 similar teeth on each margin, promarginal row juxtaposed and lower. No enlarged fang setae.

Maxillae. Inner edge gently sinuous, outer edge convex; basally and distally truncate; distally scopula not arising from pallid cuticle. With diagonal groove from base for length of labium.

Labium. As for male.

Sternum. Shield-shaped; no modifications; margins hirsute with erect bristles.

Spines. Pair of proventral spines on femora with closely set bases, on both left and right femora; only one on fe II. I: fe pv2p3d3r4; pa0; ti v2.2.2.2.2.2; me v2.2.2. II: fe pv1p3d3r4; pa0; ti p2.r1v2.2.2.2.2.2; me v2.2.2. III: fe p3d3r4; pa0; tip2d2r2v2.2.2; me p3r3v2.2.2. IV: fe p3d3r2; pa0; ti p2d2r2v2.2.2; me p3r3v1.1.1.2.2.2. Palp: fe p1d1.2; pa p1; ti p2.1d1; ta p2.1.r2.1v2 distal. On ventral tibia I, II with riased bases, and mid-distal 3 pairs very long; very long on metatarsi I, II, with 50\% overlap; third pair subdistal, very lateral.

Legs. Patella III ventrally with long deep but narrow invagination, medially forked into basal half. Trochanters darkly sclerotised. Legs break easily at patella tibia and femur-trochanter joints. Strong pre-coxal sclerites I-IV. Scopula and claw tufts entirely absent. Metatarsal membrane unilobate. Palpal tarsi spindle-shaped in lateral view, not arched; without tuft or dorsal scopula. Lateral metatarsi and tarsi I with narrow band of thickened hair like scopula; absent from ventral face. Paired claws, with 1 medial row of 5 short slender teeth basally on pro- and retroclaws.

Leg measurements of Austrotengella toddae, allotype female

$\begin{array}{llllll} & \text { I } & \text { II } & \text { III } & \text { IV } & \text { Palp } \\ \text { Femur } & 4.69 & 4.38 & 4.31 & 5.13 & 1.81 \\ \text { Patella } & 1.88 & 1.88 & 1.81 & 1.88 & 0.88 \\ \text { Tibia } & 4.50 & 4.13 & 3.69 & 4.44 & 1.13 \\ \text { Metatarsus } & 4.25 & 3.56 & 3.75 & 5.25 & \\ \text { Tarsus } & 1.88 & 1.75 & 2.19 & 2.19 & 1.31 \\ \text { Total } & 17.20 & 15.70 & 15.50 & 18.89 & 5.13\end{array}$

Trichobothria. Double band for full length on metatarsi and tibiae; on metatarsi, trichae very long. Tarsi with two irregular rows of long trichobothria for length.

Abdomen. Tracheal spiracle short, marked by slightly sclerotised square evident through cuticle.

Spinnerets. Small triangular hirsute colulus. ALS bases slightly separated, slightly bigger diameter than PLS; distal segment with sclerotised basal ring, entally indented for slightly larger spigots. PLS basally cylindrical but short with long but coniform apical segment. PMS cylindrical with spigots on dorsally extended surface of tip.

Epigyne. Large triangular septum scape-like, hirsute, deeply undercut laterally, flanked by pair of large concavities and deeply invaginated, laterodistally with pair of small distinct transverse triangular teeth. Copulatory fossa at posterior lateral junctions of septum; large columnar plate runs dorsoventrally from fossae and with posterobasal fertilisation duct (e.g., Fig. 2d).

Distribution and Habitat. Known from upland (ca. 1000m) and lowland (ca. 100m) rainforest areas in southeastern Queensland and northern New South Wales.

Remarks: Davies (1977) reported this species as "Pisauridae sp. 1". 


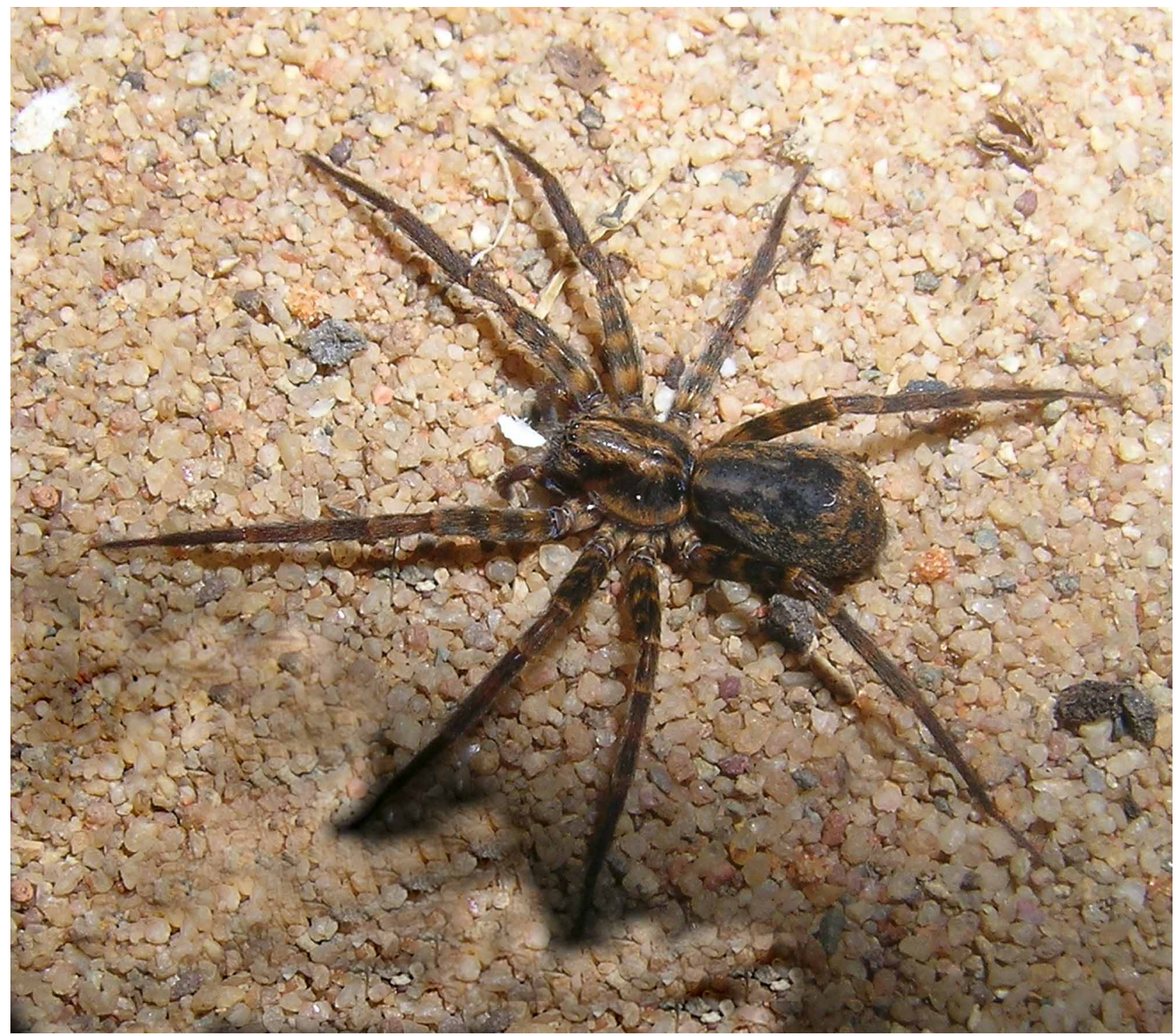

FIGURE 4. Austrotengella hackerae, sp. nov., female, habitus.

\section{Austrotengella hackerae sp. nov.}

(Figs 1a-3, 4, 5a-e, 6a, b)

Material examined: Holotype: Queensland: Tungi Creek, via Jimna, 26³9'S 152²7'E, rainforest, pitfall, 1 male, 9 Mar-15 May 1997, G. Monteith (QM S51224)

Paratypes: Tungi Creek, 263' S 152 ${ }^{\circ} 7^{\prime} \mathrm{E}$, rainforest, pitfall: 1 male, 10 Nov-29 Dec 1974, G. and S. Monteith (QM S30198); 2 males, 20 Jan - 9 Mar 1997, G. Monteith (QM S60896). Booloumba Creek, Conondale

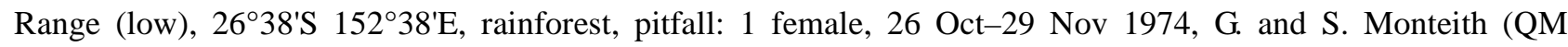
S33218); 1 female, 26 Oct-29 Nov 1974, G. and S. Monteith (QM S33212).

Other Material

Queensland: southeastern: Boombana National Park (“BCC1”), 27²4'S 152 47'E, rainforest: 1 female, 30 Oct-1 Dec 2003, QM party (QM S54869); 5 males, 31 Mar-30 Apr 2004, QM party (QM S54899); 3 males, 2 females, 1-31 Mar 2004, QM party (QM S54868); 1 female, 21 Apr 2004, C. Burwell, S. Wright, O. Seeman (QM S64144). Brookfield, Gold Creek Reservoir, 27²9'S 152 ${ }^{\circ} 55^{\prime} \mathrm{E}$, closed forest, pitfall: 1 male, 3-18 Mar 1981 , R. Raven, V. Davies (QM S72302); 1 female, 13 May-2 Jun 1981, R. Raven, V. Davies (QM S72301). Bunya Mountains National Park, 26 54'S 151 33'E, 1 female, 13 Jan 1978, A. Rozefelds (QM S51181). Dingo Creek, via Traveston, $26^{\circ} 20^{\prime} \mathrm{S} 151^{\circ} 52^{\prime} \mathrm{E}$, rainforest, pitfall: 1 female, 27 Mar-18 Aug 1975, G. and S. Monteith (QM S14177). 
Little Yabba Creek, 26 $37^{\prime}$ 'S 152 $41^{\prime} \mathrm{E}$, rainforest, pitfall: 1 male, 27 Mar-16 Jun 1975, G. and S. Monteith (QM

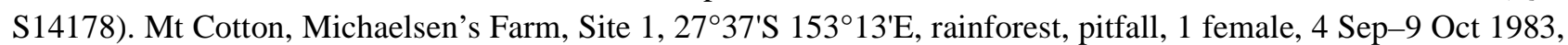
J. Gallon (QM S51979). Mt Glorious-Mt Tenison-Woods, 27²0'S 15246'E, rainforest: 1 female, 29 May 1992, G. Monteith, H. Janetzki, G. Thompson, A. Hiller (QM S19605); 1 female, 26 Jul 1985, R.J. Raven (QM S53634); 1 male, 20 Jan-26 Jun 1978, G. and S. Monteith (QM S72303); 1 male, 22 Jan-8 Apr 1975, G. and S. Monteith (QM S30404). Mt Kandanga, $26^{\circ} 27^{\prime} \mathrm{S} 152^{\circ} 34^{\prime} \mathrm{E}$, wet sclerophyll, pitfall, 1 male, 15 Jan-27 May 2002, G. Monteith (QM S72296). Mt Mee, $27^{\circ} 04^{\prime} \mathrm{S} 152^{\circ} 41^{\prime} \mathrm{E}$, rainforest, pitfall: 1 male, 3 Mar-12 Apr 1992, D.J. Cook (QM S72309); 1 female, 28 Oct 1977-20 Jan 1978, G. and S. Monteith (QM S72308); 3 females 31 Oct 1978-13 Feb 1979, G. and S. Monteith (QM S14187). Mt Tamborine, Palm Grove, $27^{\circ} 55^{\prime} \mathrm{S} 153^{\circ} 11^{\prime} \mathrm{E}$, rainforest, pitfall: 1 male, 1 female, 26 Oct-14 Dec 1974, G. and S. Monteith (QM S30466); 1 female, 26 Oct-14 Dec 1974, G. and S. Monteith (QM S30440); 1 male, 14 Dec 1974-22 Mar 1975, G. and S. Monteith (QM S30380). Ravensbourne National Park, $27^{\circ} 21^{\prime}$ S $152^{\circ} 11^{\prime} E$, rainforest, pitfall: 1 female, 10 Nov 1974-12 Jan 1975, G. and S. Monteith (QM S30186); 2 males, 3 females, 30 Mar-1 Jun 1975, G. and S. Monteith (QM S30385); 1 female, 10 Nov 1974-12 Jan 1975, G. and S. Monteith (QM S30465). Rochedale State Forest, $27^{\circ} 37^{\prime} \mathrm{S} 153^{\circ} 08^{\prime} \mathrm{E}$, ironbark woodland: 1 male, 30 Aug 1979, R. Raven, V. Davies (QM S33120); 1 male, 7 Oct 1980, R. Raven, V. Davies (QM S33118). Upper Brookfield, $27^{\circ} 29^{\prime} \mathrm{S} 152^{\circ} 55^{\prime} \mathrm{E}$, rainforest, pitfall: 1 male, $27 \mathrm{Feb}-20$ May 1976, G. and S. Monteith (QM S28834); 1 male, 18 Mar-23 Apr 1981, V. Davies, R. Raven (QM S72297). Upper East Kilcoy Creek, $26^{\circ} 45^{\prime} \mathrm{S} 152^{\circ} 38^{\prime} \mathrm{E}$, rainforest, pitfall: 10 males, 1 female, 9 Mar-15 May 1997, G. Monteith (QM S72300); 1 male, 1 female, 9 Mar-15 May 1997, G. Monteith (QM S39665). Wrattens Camp, via Widgee, 261' S $152^{\circ} 22^{\prime} \mathrm{E}$, rainforest, pitfall: 1 female, 11 Aug-10 Nov 1974, G. and S. Monteith (QM S30384); 2 females, 28 Mar-16 Jun 1975, G. and S. Monteith (QM S30415); 1 female, 16 Jun-23 Aug 1975, G. and S. Monteith (QM S30390); 1 male, 29 Dec 1974-28 Mar 1975, G. and S. Monteith (QM S30193). 1 male, Bellthorpe, 26 $50^{\circ} \mathrm{S} 152^{\circ} 41^{\prime} \mathrm{E}$, rainforest, pitfall, 9 Mar-15 May, G. and S.

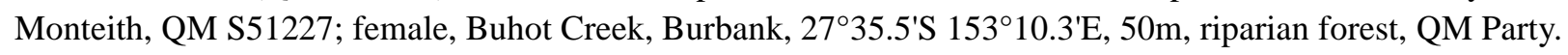
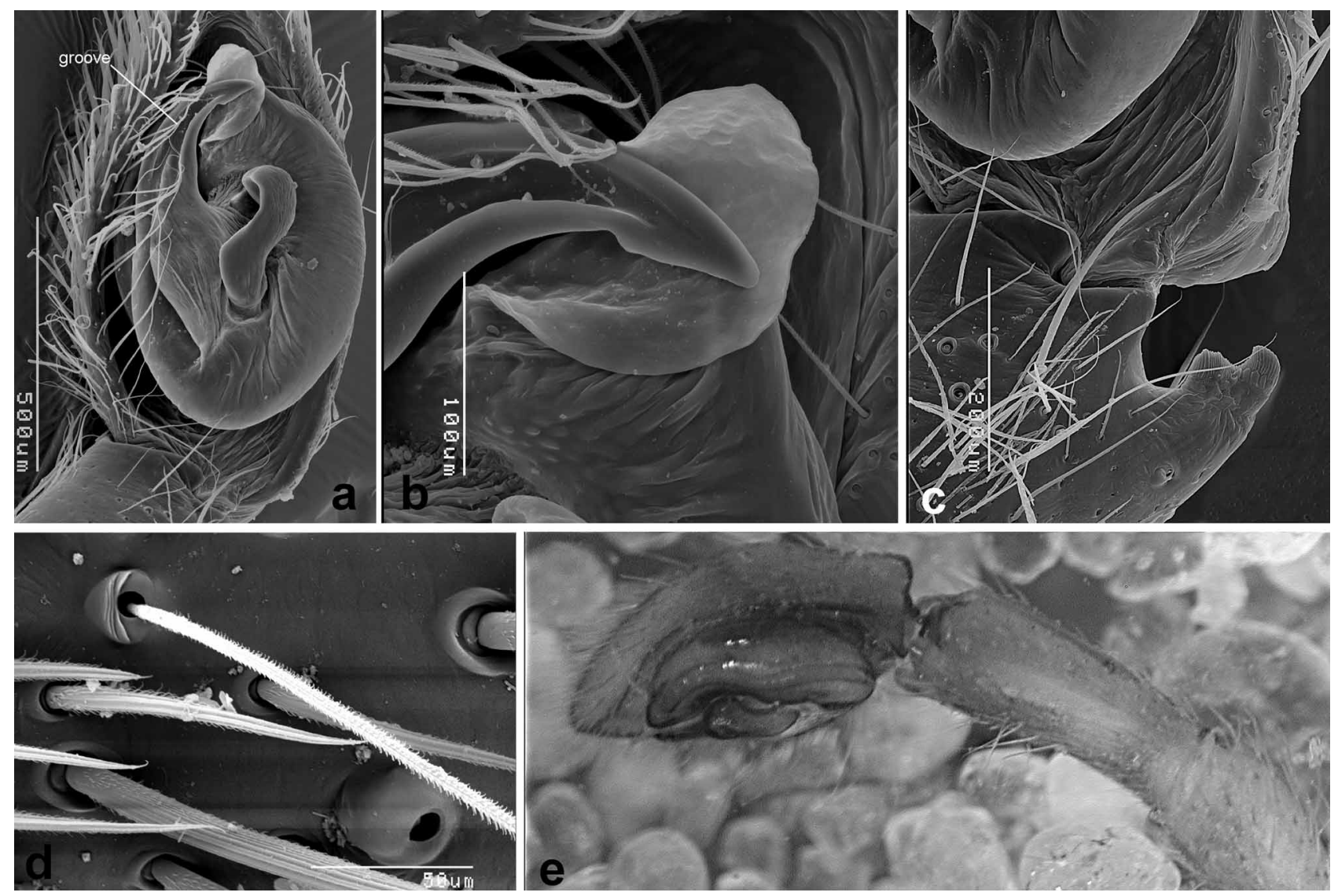

FIGURE 5. Austrotengella hackerae, sp. nov., male palp, QM S30466, scanning electron micrographs, a-d: a, cymbium and bulb, ventral view; b, apex of embolus overlying flaired hyaline conductor, ventral view; c, retrobasal cymbium and tibial apophysis, ventral view. d. tarsal organ, trichobothrial base and cuticle. e. patella, tibia and cymbium, retrolateral view. 

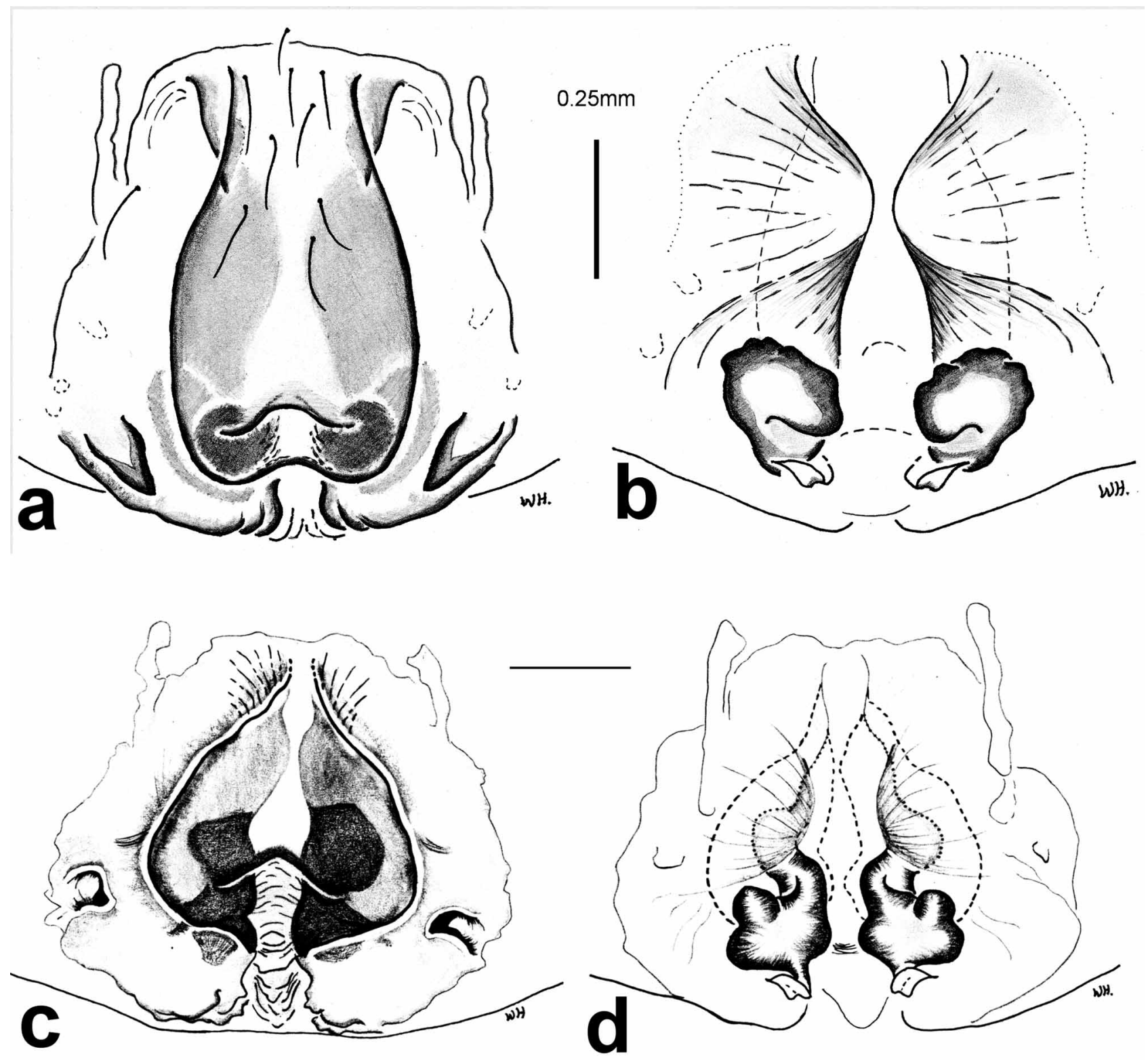

FIGURE 6. Austrotengella species, female epigynum: a, b. A. hackerae, sp. nov., external (a) and internal view (b); c, d, A. hebronae, sp. nov., AM KS42951, external (c) and internal view (d). Scale lines $=0.25 \mathrm{~mm}$.

Diagnosis: Males differ from those of A. monteithi in the longer, more slender median apophysis and the ventral groove on the embolus is open for its length and from $A$. wrighti in the small retroventral flange on the cymbium and the simple tapering embolic tip. Females diifer from those of all other species in the less anteriorly narrowed anterior "neck" of the median epigynal scape and its overall narrowness.

Etymology: In honour of Penelope Hacker, a much admired animal carer, and in whose backyard at Mt Glorious the species continues to thrive.

Description (Holotype male QM S51224)

Caparace 2.93 long, 2.15 wide. Abdomen 2.70 long, 1.56 wide.

Colour in alcohol. Pattern on carapace and abdomen faded.

Legs. Tibia to tarsi of all legs with long recurved hairs for length on all faces. Spines: Tibiae I, II: 5 strong pairs ventrally plus pair of small on distal edge; metatarsi I, II with 3 strong pairs ventrally. Claws: paired claws dentate, not noticeably long.

Palp. Distal cymbium with noticeably denser brush of hair; cymbium viewed retrolaterally with distinct basodorsal conical mound; retroventral flange small. Tibial apophysis subdistal with pair of dissimilar apices; ventral tibia-cymbial interlocking process small but distinct; median apophysis long, slender, apically folded, origin 
subcentral on tegulum, shorter in overall length than apically pointed embolus, median apophysis lies within longitudinal extent of embolus. Ventral groove in embolus a distinctly open groove for length.

Leg measurements of Austrotengella hackerae, holotype male

$\begin{array}{llllll} & \text { I } & \text { II } & \text { III } & \text { IV } & \text { Palp } \\ \text { Femur } & 3.04 & 2.88 & 2.75 & 3.13 & 1.19 \\ \text { Patella } & 1.36 & 1.38 & 1.06 & 0.88 & 0.56 \\ \text { Tibia } & 3.13 & 2.69 & 2.19 & 2.56 & 0.69 \\ \text { Metatarsus } & 2.75 & 2.13 & 2.25 & 2.88 & 0.00 \\ \text { Tarsus } & 1.56 & 1.31 & 1.13 & 1.25 & 1.00 \\ \text { Total } & 11.83 & 10.38 & 9.38 & 10.69 & 3.44\end{array}$

Description (Allotype female QM S33212)

Caparace 4.03 long, 3.13 wide. Abdomen 4.41 long, 2.54 wide.

Colour. Pattern on abdomen faded but more evident than in male.

Legs. Spines, tibiae and metatarsi I, II as in male. Paired claws noticeably elongate, especially on IV.

Epigyne. An almost parallel-sided median plate, slightly widened at posterior third, at which point medially is a short recurved ridge over the posterior invagination from the otherwise distinct posterior margin; bases of short concial lateral teeth arise just posterior of the line of recurved ridge, teeth directed diagnoally posteriad and line of apices lies just posterior to line of posterior margin. Genital opening plugged for two-thirds its length from proximad by lamellate portion of male palp.

Leg measurements of Austrotengella hackerae, allotype female

$\begin{array}{llllll} & \text { I } & \text { II } & \text { III } & \text { IV } & \text { Palp } \\ \text { Femur } & 2.89 & 2.61 & 2.50 & 3.11 & 1.11 \\ \text { Patella } & 1.33 & 1.22 & 1.11 & 1.17 & 0.56 \\ \text { Tibia } & 2.61 & 1.83 & 2.06 & 2.33 & 0.72 \\ \text { Metatarsus } & 2.33 & 2.67 & 2.28 & 2.83 & 0.00 \\ \text { Tarsus } & 1.00 & 0.78 & 1.00 & 1.22 & 0.89 \\ \text { Total } & 10.17 & 9.11 & 8.94 & 10.67 & 3.28\end{array}$

Distribution and Habitat. This most widespread species occurs from Wrattens Camp in the north and as far south along the Conondale Ranges to Mt Tamborine, one range north of Lamington National Park. It occurs coastally in a retreating rainforest (Buhot) in south-eastern Brisbane west to the Great Dividing Range at Ravensbourne. All areas are rainforest or at least closed forest.

Remarks: One female (QM S19605) was taken in a Myrmecia nest.

\section{Austrotengella hebronae, sp. nov.}

(Figs 3, 6c, d)

Material examined: Holotype: female, Mt Boss State Forest (valley), $31^{\circ} 12^{\prime} \mathrm{S} 152^{\circ} 24^{\prime} \mathrm{E}$, New South Wales, Oct 1980, G. A. Webb, AM KS 42851.

Diagnosis: The female differs from those of $A$. wrighti by the more anterior position of the epigynal teeth, the relatively narrower median plate and the recurved angular ridge posteriorly on the plate. Males are unknown.

Etymology: In honour of Mrs Wendy Hebron, for her much appreciated support in illustration, sorting and collection management.

Description (Holotype female AM KS42851)

Carapace 4.68 long, 3.12 wide. Abdomen damaged.

Colour. Carapace yellow brown with slightly darker markings medially. Abdomen colour and pattern faded.

Spines. I: femur pv2p2r3; tibia p2r2pv5rv5; me p1r1v2.2.2. II: femur pv1p3d3r3; tibia p2r1pv5 rv5; me p1r1v2.2.2. III: fe pv1p3d3r4; ti p2d2r2v2.2.2; me p3r3v2.2.2. IV: fe p4d3r2; ti p2d2r2v2.2.2; me p3r2v2.2.2. Palp: fe p1d1.2; ti pv1d1.2r1; ti p2pv1 very long; ta p1r2, two basal very long. 


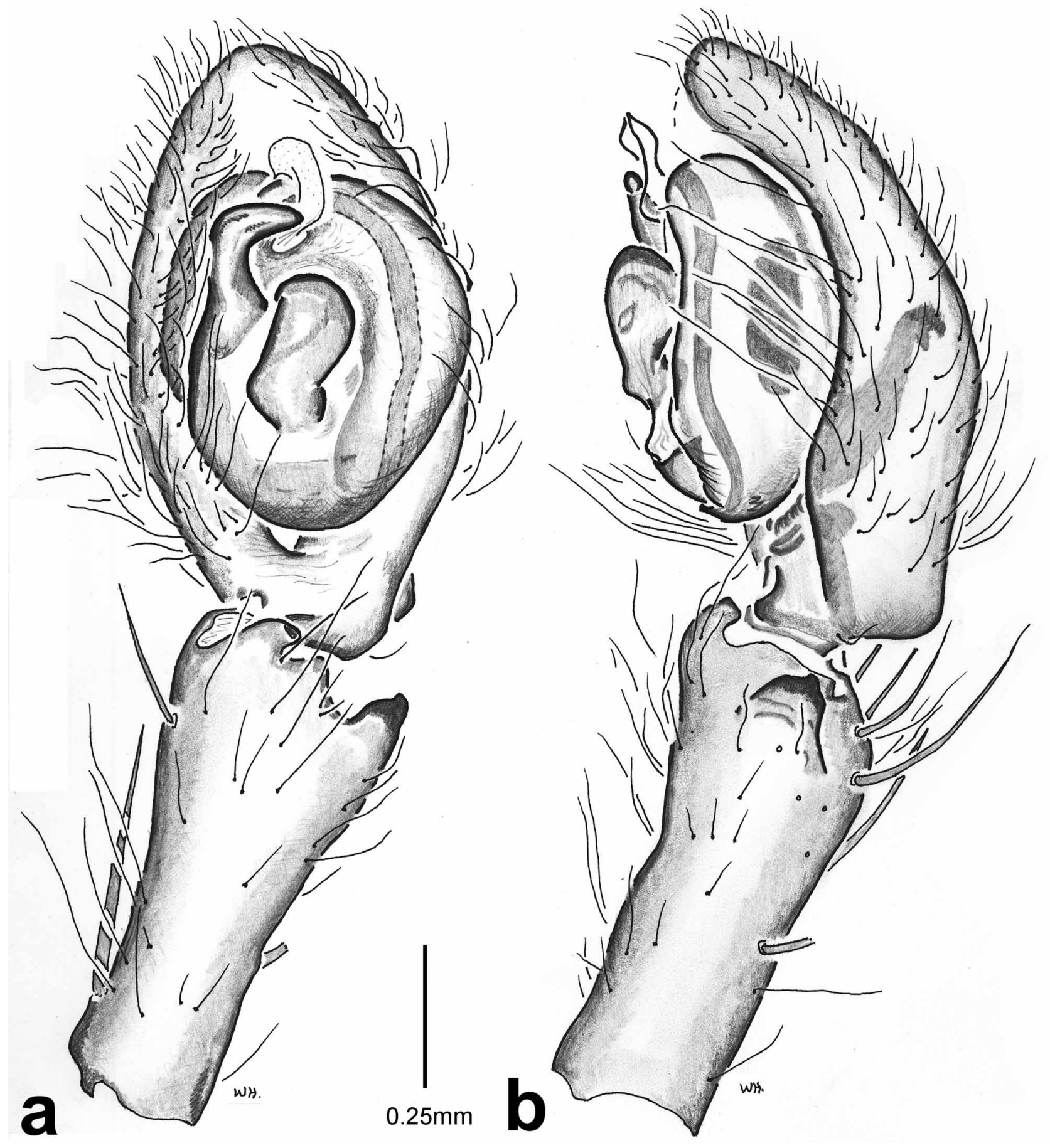

FIGURE 7. Austrotengella monteithi, sp. nov., holotype male QM S57227, palpal tibia, cymbium and bulb: ventral view (a) and retrolateral view (b).

Claws. Paired claws long, slender curved with 2-3 small teeth basally; on leg IV, very long. Third claw long, distinct, bare.

Spinnerets. 5-6 large conical spigots dorsolaterally on PMS; PMS themselves, as long as PLS, conical.

Epigyne. Broad, ventrally domed, heart-shaped plate with narrow septum anteriorly; posterolaterally with transverse tooth on each side, teeth subdistal, just posterior of widest point of median plate and clearly separated from epigastric groove; teeth short and directed downward, posteriorly and medially. Recurved angular ridge posteriorly on plate.

Distribution: Known only from Mt Boss State Forest, northern New South Wales. This is the southern-most record of this genus. 
Leg measurements of Austrotengella hebronae, holotype female

$\begin{array}{llllll} & \text { I } & \text { II } & \text { III } & \text { IV } & \text { Palp } \\ \text { Femur } & 4.75 & 4.75 & 4.06 & 5.00 & 1.50 \\ \text { Patella } & 2.19 & 2.13 & 1.81 & 1.81 & 0.94 \\ \text { Tibia } & 4.75 & 4.44 & 3.81 & 4.75 & 1.31 \\ \text { Metatarsus } & 3.94 & 3.94 & 4.38 & 5.69 & 0.00 \\ \text { Tarsus } & 2.19 & 2.13 & 2.00 & 2.13 & 1.56 \\ \text { Total } & 17.81 & 17.38 & 16.06 & 19.38 & 5.31\end{array}$

Austrotengella monteithi, sp. nov.

(Figs 3, 7a, b, 8a-f, 9a-c, 10a, b)

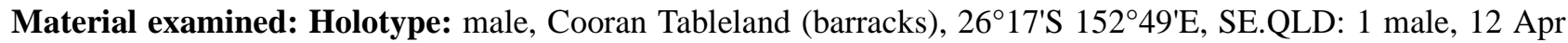
1995, G.Monteith, K. Koch, G. Thompson (QM S57227).

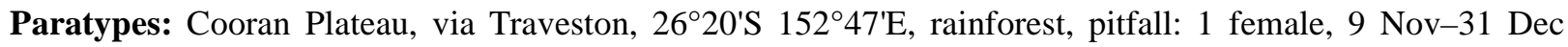
1974, G. and S. Monteith (QM S33221); 2 females, 28 Mar-13 Aug 1975, G. and S. Monteith (QM S14186=allotype, plus one for juvenile); Cooloola, Lake Poona, $26^{\circ} 12^{\prime} S 1^{\circ} 153^{\circ} 03^{\prime}$ E, SE.Q, April 1979, G. Monteith (QM

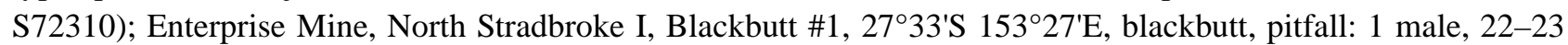
Jan 2002, D.J. Cook (QM S56470); 1 male, 8-22 Jan 2002, Queensland Museum Party (QM S55776); 1 male, 0.5k N Cooran Tableland (barracks), 26 ${ }^{\circ} 17^{\prime} \mathrm{S} 152^{\circ} 50^{\prime} \mathrm{E}$, SE.QLD, 16 Jan-27 May 2002, flight intercept, rainforest, G.Monteith (QM S86414).

Etymology: In honour of Dr Geoff Monteith without whose strident activities over the past 35 years the invertebrate fauna of eastern Australia would be much more poorly known.

Diagnosis: Males differ from those of $A$. toddae in smaller subbasal mounds on RTA and relatively broader median apophysis, and from those of A. hackerae in the broad retrobasal cymbial flange, distinct retrodorsal cymbial cone, and the ventral groove of the embolus is open only on the tip. Females differ from thoose of $A$. hackerae in the shorter more deeply recurved invagination on the posterior septum and relatively broader anterior portion of the anterior septum.

Description (Holotype male QM S57227)

Caparace 4.43 long, 3.58 wide. Abdomen 3.69 long, 2.27 wide.

Colour. Pattern on carapace and abdomen similar to A. hackerae (Fig. 4).

Palp. RTA subdistal with simple single apex with two small mounds subdistally of tip; ventral tibia-cymbial interlocking process distinct; lateral one not so evident; basodorsal cymbium rounded, not posteriorly projected (Fig. 7b cf. 5e); median apophysis large, origin is central on tegulum; similar in overall length to bluntly tipped embolus; longitudinal extents overlap by $30-50 \%$. Ventral groove of embolus closed for almost its entire length, only open near the tip.

Leg measurements of Austrotengella monteithi, holotype male

$\begin{array}{llllll} & \text { I } & \text { II } & \text { III } & \text { IV } & \text { Palp } \\ \text { Femur } & 4.38 & 4.13 & 3.44 & 4.06 & 1.13 \\ \text { Patella } & 1.63 & 1.50 & 1.19 & 1.31 & 0.69 \\ \text { Tibia } & 4.69 & 3.94 & 2.88 & 3.63 & 0.75 \\ \text { Metatarsus } & 4.63 & 3.50 & 3.19 & 4.69 & 0.00 \\ \text { Tarsus } & 2.00 & 1.75 & 1.63 & 1.81 & 0.50 \\ \text { Total } & 17.31 & 14.81 & 12.31 & 15.50 & 3.06\end{array}$

Description (Allotype female QM S14186)

Caparace 3.99. long, 3.65 wide. Abdomen 4.40 long, 3.05 wide.

Colour (formalin-fixed). Carapace orange brown with brown edges and broad brown "donut" area around fovea and caput, central pallid zone in two parts, yellow ovoid area behind eyes and trianguloid area around fovea. 


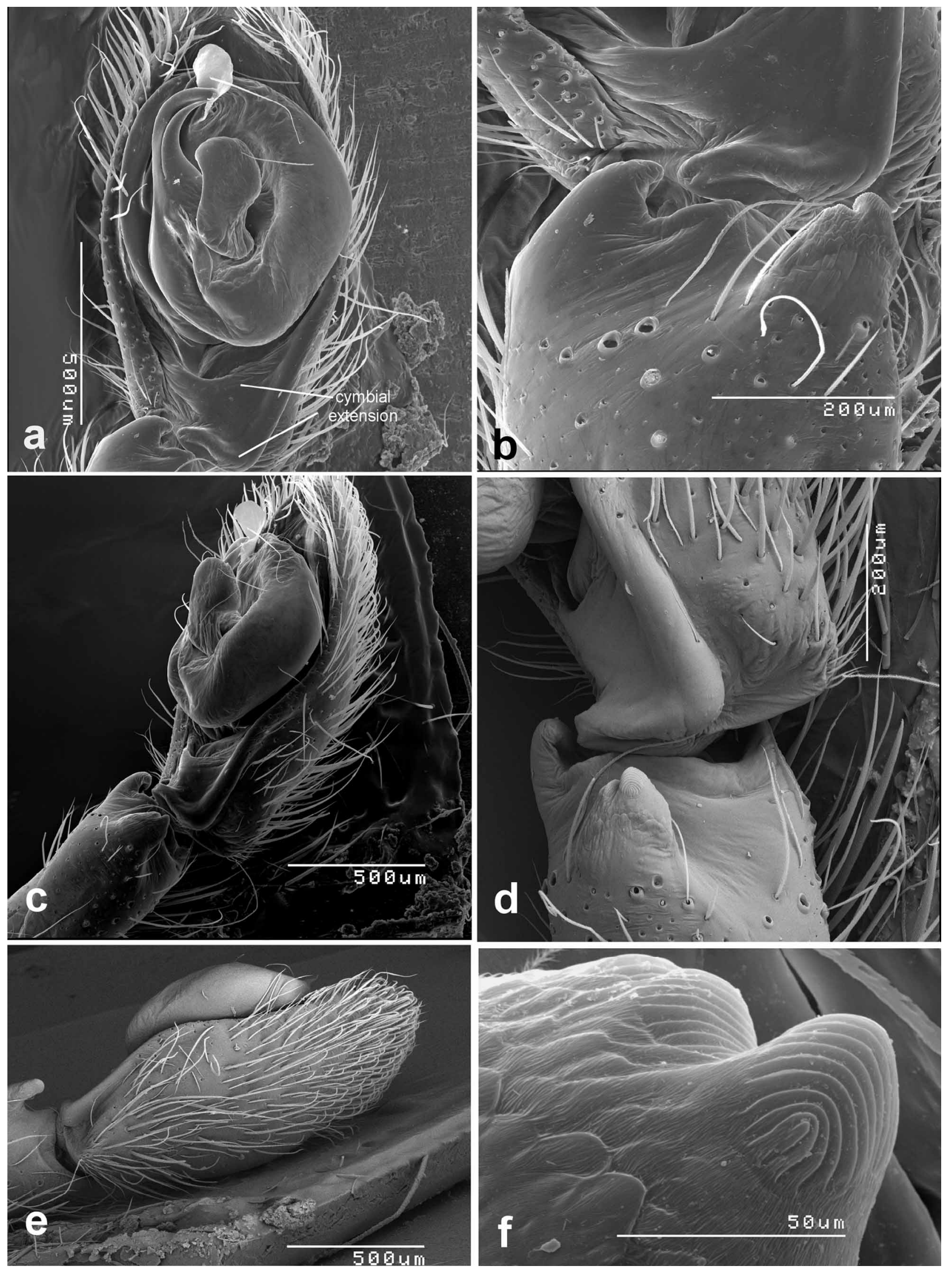

FIGURE 8. Austrotengella monteithi, sp. nov., male palp, QM S36414, scanning electron micrograph: a, cymbium and bulb, ventral view; b, distal tibia and basal cymbium, retroventral view; c, tibia, cymbium and bulb, retroventral view; d, distal tibia and basal cymbium, retrodorsal view; e, tibia and cymbium, dorsal biew; f, lamellate apices of tibial apophysis, retrolateral view. 

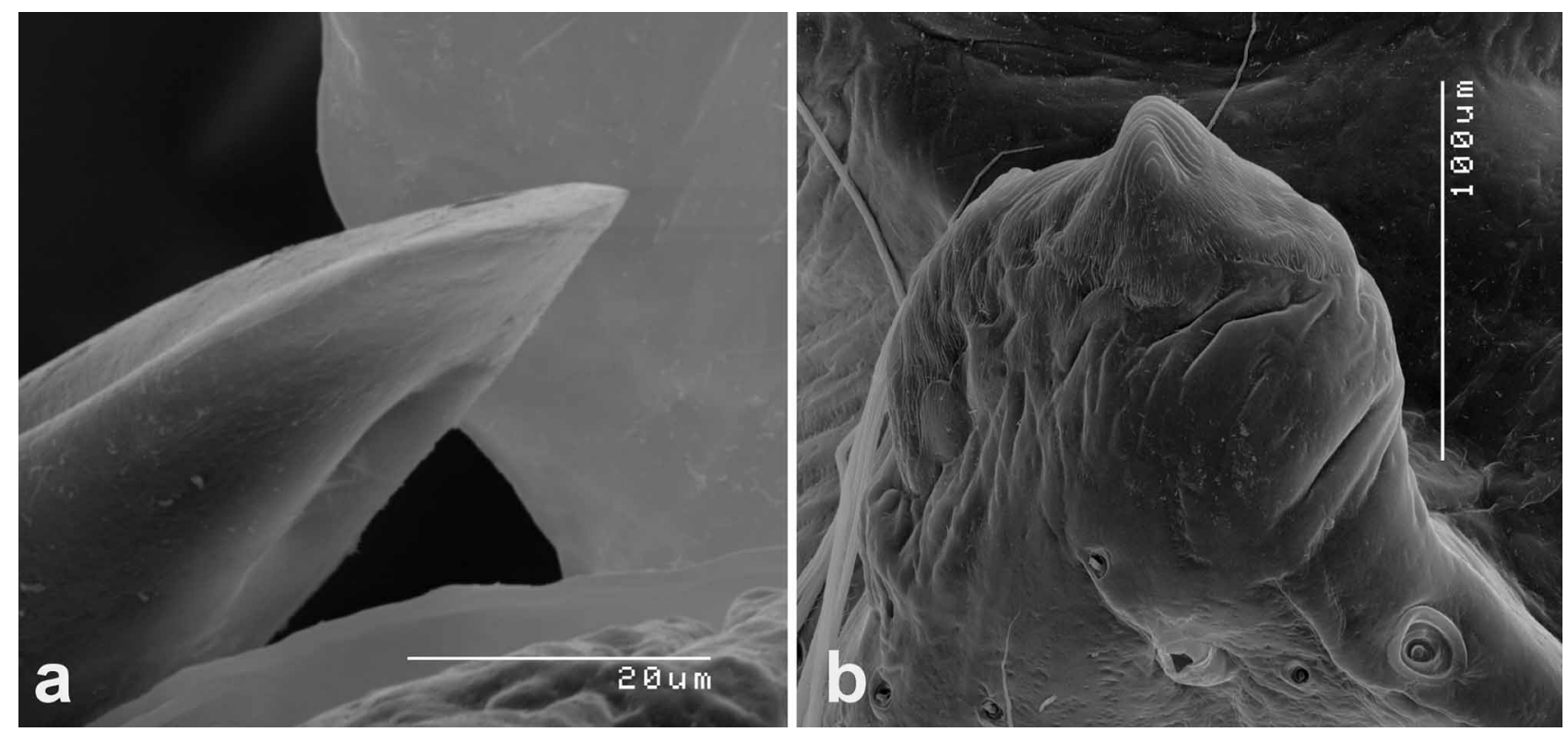

FIGURE 9. Austrotengella monteithi, sp. nov., male palp, QM S36414, scanning electron micrograph: a, tip of embolus, showing ventral opening; $b$, tibial apophysis, retrolateral view.

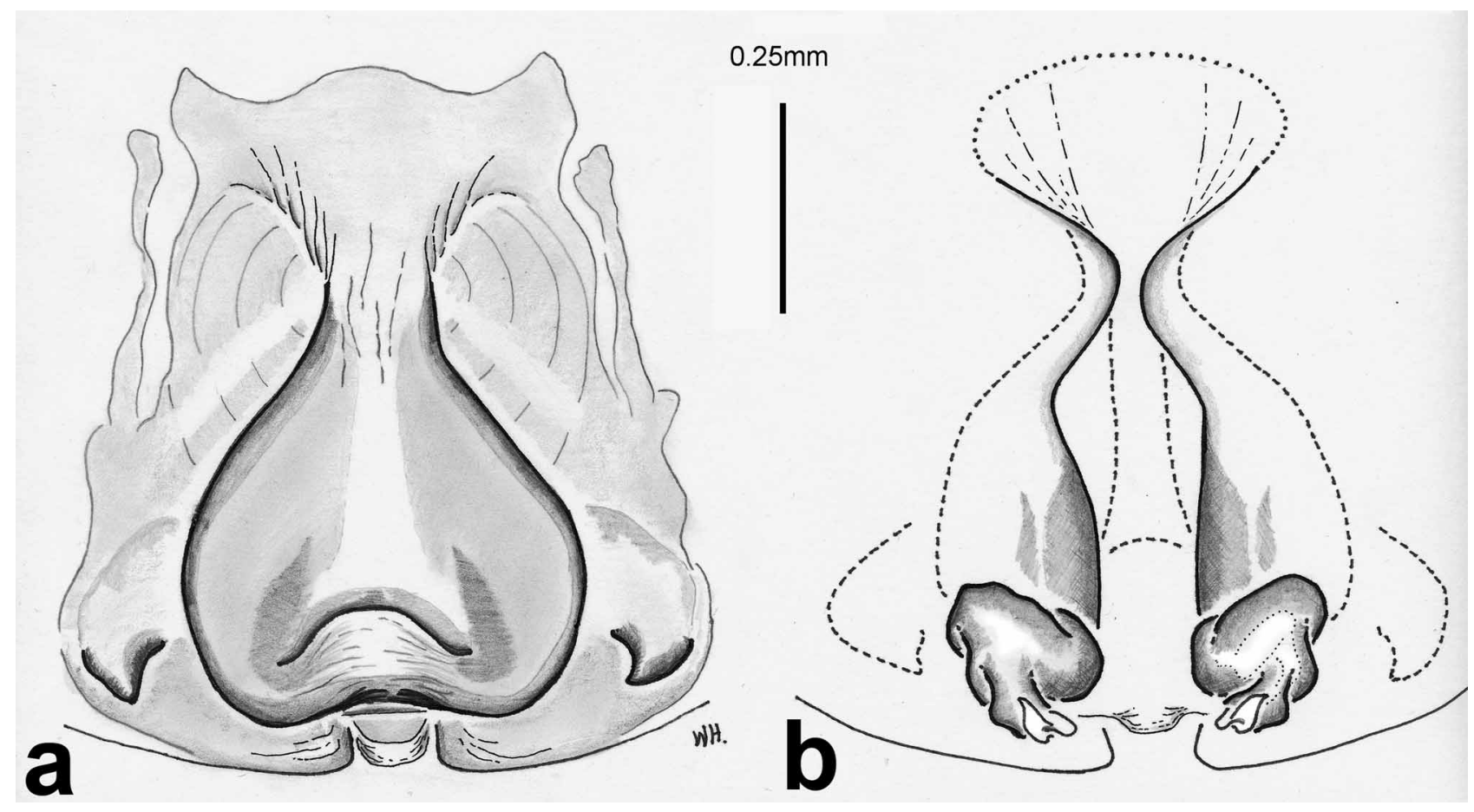

FIGURE 10. Austrotengella monteithi, sp. nov., allotype female QM S14186, epigyne : external (a) and internal (b) views.

Chelicerae orange brown; coxae pallid, dorsally with wide median dark stripe. Legs with 3 irregular annulations on femora, otherwise dark orange brown. Abdomen collapsed, venter mottled pallid, marginally mottled.

Carapace. Glabrous except for pile of long white hairs in head region and around eyes.

Eyes. From above, configuration is 2.4.2. AER recurved from above. PER in two separated rows.

Spines. Femora: I, fe pv2 strong p3d2r2; II, pv2 weak p2d3r4; III, p4d3r4; IV, p3d3r2; palp, p1d1.2. Patellae, I, II, 0; III, IV, palp, d1. Tibiae: I, II v2.2.2.2.2 + 2 distal; III, IV, p2d2r2v2.2.2; palp, p2d1. Metatarsi: I, II, v2.2.2; III, p2r3v2.2.2; IV, p2r1v2.1.2.3. Palpal tarsus, p2.1d1r1v2.

Claws. Long, curved with 3-4 small teeth basally. Palpal claw long with 3 basal teeth.

Spinnerets. Invaginated. 
Leg measurements of Austrotengella monteithi, allotype female

$\begin{array}{llllll} & \text { I } & \text { II } & \text { III } & \text { IV } & \text { Palp } \\ \text { Femur } & 2.58 & 2.50 & 2.38 & 2.85 & 0.86 \\ \text { Patella } & 1.29 & 1.25 & 0.78 & 1.02 & 0.55 \\ \text { Tibia } & 2.58 & 2.34 & 1.95 & 2.50 & 0.66 \\ \text { Metatarsus } & 2.23 & 2.11 & 2.07 & 3.13 & 0.00 \\ \text { Tarsus } & 1.05 & 1.09 & 1.09 & 1.29 & 0.98 \\ \text { Total } & 9.73 & 9.30 & 8.28 & 10.78 & 3.05\end{array}$

Epigyne. Long rectanguloid plate with short narrow septum anteriorly; septum quickly widens to cordiform, posterolaterally with transverse tooth on each side, teeth subdistal, just posterior to widest part of median plate, well back from epigastric groove; teeth short, directed diagonally and medially. Posterior margin of septum with broad shallow recurved ridge.

Distribution and Habitat. Known only from rainforest on the Cooran Plateau, and coastal rainforests at Cooloola and North Stradbroke Island, southeastern Queensland.

\section{Austrotengella plimeri, sp. nov.}

(Figs 3, 11a-d)

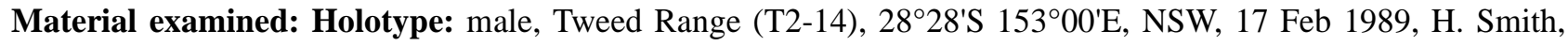
Hines, Pugh, Webb, AM KS 48914.

Paratype: allotype, female, QMS30401, 1 fem., Brindle Creek, Wiangaree, $28^{\circ} 28^{\prime} \mathrm{S} 153^{\circ} 03^{\prime} \mathrm{E}$, NSW, rainforest, pitfall, 17 Nov-27 Dec 1974, G. and S. Monteith.

Diagnosis: the male is similar to those of A. toddae from which they differ by the relatively smaller median apophysis and distal embolus, which are not or hardly overlapping in longitudinal extents and the chelate RTA. Ventral groove of embolus open for its entire length.

Etymology: In honour of Professor Ian Plimer, geologist, for his provocative contributions to issues of climate change.

Description (Holotype male AM KS 48914)

Carapace 4.45 long, 3.44 wide. Abdomen damaged.

Palp. RTA distal, distally chelate with each "claw" of similar size. Ventral tibia with small triangular apophysis. Basodorsal cymbium rounded, not posteriorly projected (Fig. 11b); median apophysis small, origin basal on tegulum; slightly longer than bluntly-tipped embolus, longitudinal extents only very slightly overlapping, if at all. Ventral groove of embolus clearly open for its entire length.

Spines. Leg I missing. Tibia II: v.2.2.2.2.2; me v2.2.2. Otherwise like A. toddae male.

Claws. Paired claws long, slender curved with 2-4 small teeth in basal fifth of claw. Third claw long, curved bare.

Leg measurements of Austrotengella plimeri, holotype male

$\begin{array}{llllll} & \text { I } & \text { II } & \text { III } & \text { IV } & \text { Palp } \\ \text { Femur } & 0.00 & 6.06 & 5.38 & 6.27 & 2.04 \\ \text { Patella } & 0.00 & 2.32 & 1.77 & 1.91 & 0.95 \\ \text { Tibia } & 0.00 & 5.86 & 4.90 & 5.72 & 1.23 \\ \text { Metatarsus } & 0.00 & 5.59 & 5.38 & 7.15 & 0.00 \\ \text { Tarsus } & 0.00 & 3.34 & 2.72 & 3.13 & 1.29 \\ \text { Total } & 0.00 & 23.16 & 20.16 & 24.18 & 5.52\end{array}$

Description (Allotype female QMS 30401)

Carapace 2.41 long, 2.03 wide. Abdomen 2.53, 2.03 wide.

Colour in alcohol. Carapace yellow brown with subcentral darker band extending forward to lateral of eyes; dark spindle-shaped mark anterior to fovea. Abdomen pallid, pattern faded.

Eyes. From above, AME on tubercle that slightly overhangs clypeus. 

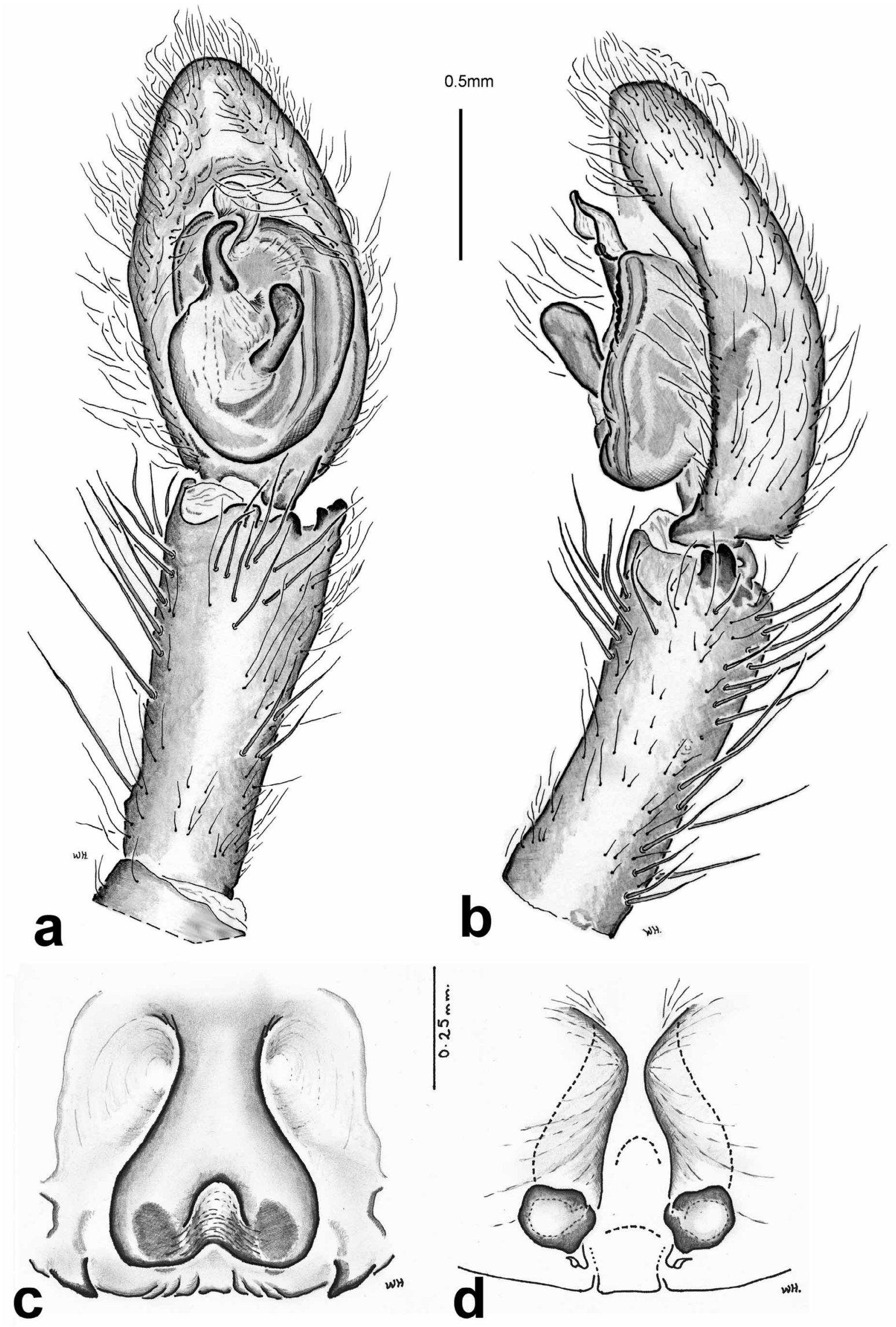

FIGURE 11. Austrotengella plimeri, sp. nov., male, palpal tibia, cymbium and bulb: ventral view (a) and retrolateral view (b). Scale line $=0.5 \mathrm{~mm}$. Allotype, female QMS30401 c, d. epigyne, external (c) and internal (d) views. 
Spines. None on pedal patellae. Femur I with proventral two strong spines distally plus p1d3r3. Femur II p3d3r4; ti also with p2. Tibiae I, II with 5 pairs of long spines and one small distal pair; metatarsi I, II with 3 strong pairs ventrally. III: fe p5d4r3; ti p2d2r2v.2.2.2; me p1.2.1r1.1.1v2.2.3. IV: fe p3d3r2; ti p2d2r2v2.2.2; me p1.1r1.1.2v2.2.3. Palp: fe p1d1.2; pa p1; ti d2p3; ta p3d1r1 plus small distoventral pair.

Epigyne. Rectanguloid plate with broad septum anteriorly; posterolaterally with transverse tooth on each side, teeth distal, posterior of median plate on line of epigastric groove; teeth short, directed diagonally medially. Posterior margin of septum with deeply U-shaped subdistal invagination.

Distribution: Known only from Tweed Range, northeastern New South Wales.

\section{Austrotengella wrighti, sp. nov.}

(Figs 3, 12a, b, 13a-d)

Material examined: Holotype: male, Mt French, via Boonah, SE.Q., $28^{\circ} 00^{\prime} \mathrm{S} 152^{\circ} 36^{\prime} \mathrm{E}$, rainforest, pitfall, G. and S. Monteith, 25 Aug-10 Oct 1976, S28845.

Paratypes: Queensland: Mt French, via Boonah, 2800'S 152 $36^{\prime} \mathrm{E}$, rainforest, pitfall: 2 males, taken with holotype, ex S28845; 2 males, 8 May-25 Aug 1976, G. and S. Monteith (QM S28836); 2 females, 22 Feb-8 May 1976, G. and S. Monteith (QM S28842); 1 male, 5 Oct 1975-22 Feb 1976, G. and S. Monteith (QM S28843); 3 males, 3 females, 5 Oct 1975-22 Feb 1976, G. and S. Monteith (QM S28844). New South Wales. 13 males, Top end of Tucker Box Road, Beaury State Forest, NSW 28 28'S 152²4'E, 740m, M. Gray, G. Cassis, 4 Feb-3 Apr 1993, AMKS 36272.

Etymology: In honour of Mr Jeff Wright, Queensland Museum, whose consummate skills in the photography of small terrestrial invertebrates are honored.

Diagnosis: Females differ from those of $A$. toddae by the broader epigynal plate without posterior deep invagination; males of the two species are best separated by the clearly dissimilar lobes of the RTA. Males differ from those of $A$. monteithi in the broad retroventral cymbial flange and the apex of the embolus is arrowhead-like. Males with conical extension of cymbium basally over tibia; epigyne with broad anterior septum and posteriorly set lateral teeth.

Description (Holotype male QM S28845)

Carapace 3.94 long, 3.25 wide. Abdomen 3.88 long, 2.31 wide.

Carapace, legs, spines and chelicerae as in A. toddae.

Leg measurements of Austrotengella wrighti, holotype male

$\begin{array}{llllll} & \text { I } & \text { II } & \text { III } & \text { IV } & \text { Palp } \\ \text { Femur } & 4.13 & 4.00 & 3.75 & 4.44 & 1.81 \\ \text { Patella } & 1.88 & 1.75 & 1.50 & 1.63 & 0.63 \\ \text { Tibia } & 4.25 & 3.88 & 3.31 & 4.06 & 0.88 \\ \text { Metatarsus } & 3.75 & 3.56 & 3.75 & 5.19 & - \\ \text { Tarsus } & 2.06 & 1.88 & 1.94 & 1.94 & 1.63 \\ \text { Total } & 16.07 & 15.07 & 13.94 & 17.26 & 4.95\end{array}$

Palp: tibia with large subdistal retrodorsal apophysis with two blunt apices. Tibia distally with 2 apophyses: ventrally a process forms notch in which complementary lobe on retrobasal cymbium interlocks; prolateral of that process a concave invagination prodorsally bounded by low ridge, which fits into a groove on prodorsal cymbium basally. Cymbium dorsally forms cone extending basally over distal tibia; dorsal scopula absent; retrolateral groove absent; retroventral flange of cymbium distinctly widened. In resting position, cymbium twisted so that normal ventral face diagonally faces ectally. Tegulum conical with large median apophysis and slightly smaller embolus; longitudinal extents of which overlap by 30-50\%. Ventral groove of large embolus widely open for its length and tip arrowhead-like.

Description (Allotype Female QM S28842)

Carapace 3.60 long, 3.80 wide. Abdomen 3.88 long, 2.60 long.

Colour. As for A. toddae but coxae dorsally yellow brown with broad light shadow stripe. 
Epigyne. Broad, ventrally flat or slightly concave, broadly pear-shaped with broad anterior septum, widest point in posterior fifth, posteriorly slightly concave; lateral teeth set posterior of widest point, short conical directed medially and posteriorly. Genital opening plugged with more than just embolus.

Spinnerets. Expanded, two lines, each of 4, of largest spigots on spinnerets on PMS dorsally and, as with ALS and PLS apically with ring of smaller but long spigots; PMS as long as PLS, conical.

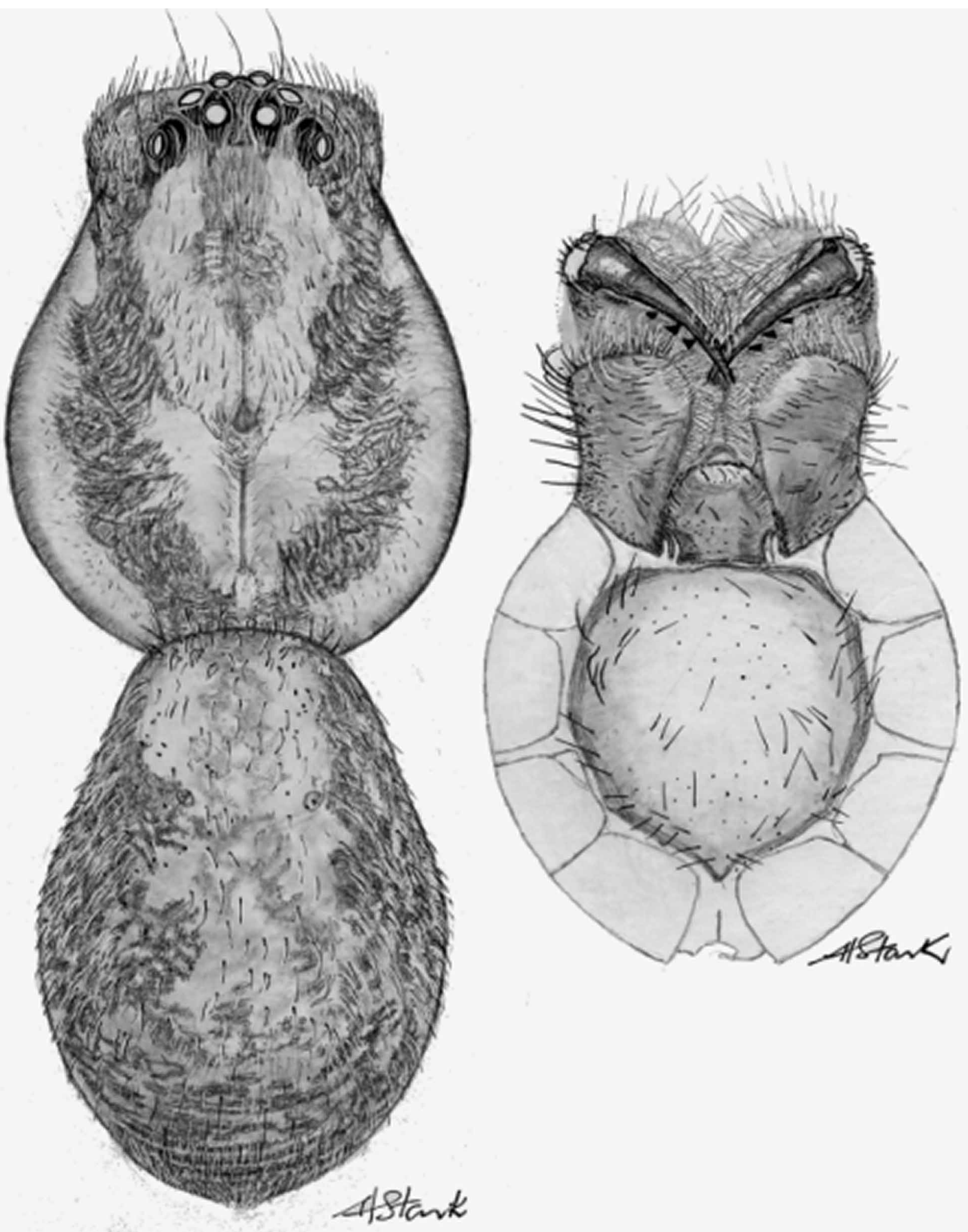

FIGURE 12. Austrotengella wrighti, sp. nov., holotype male QMS 28845, habitus (a), sternum, maxillae, labium and chelicerae (b). 

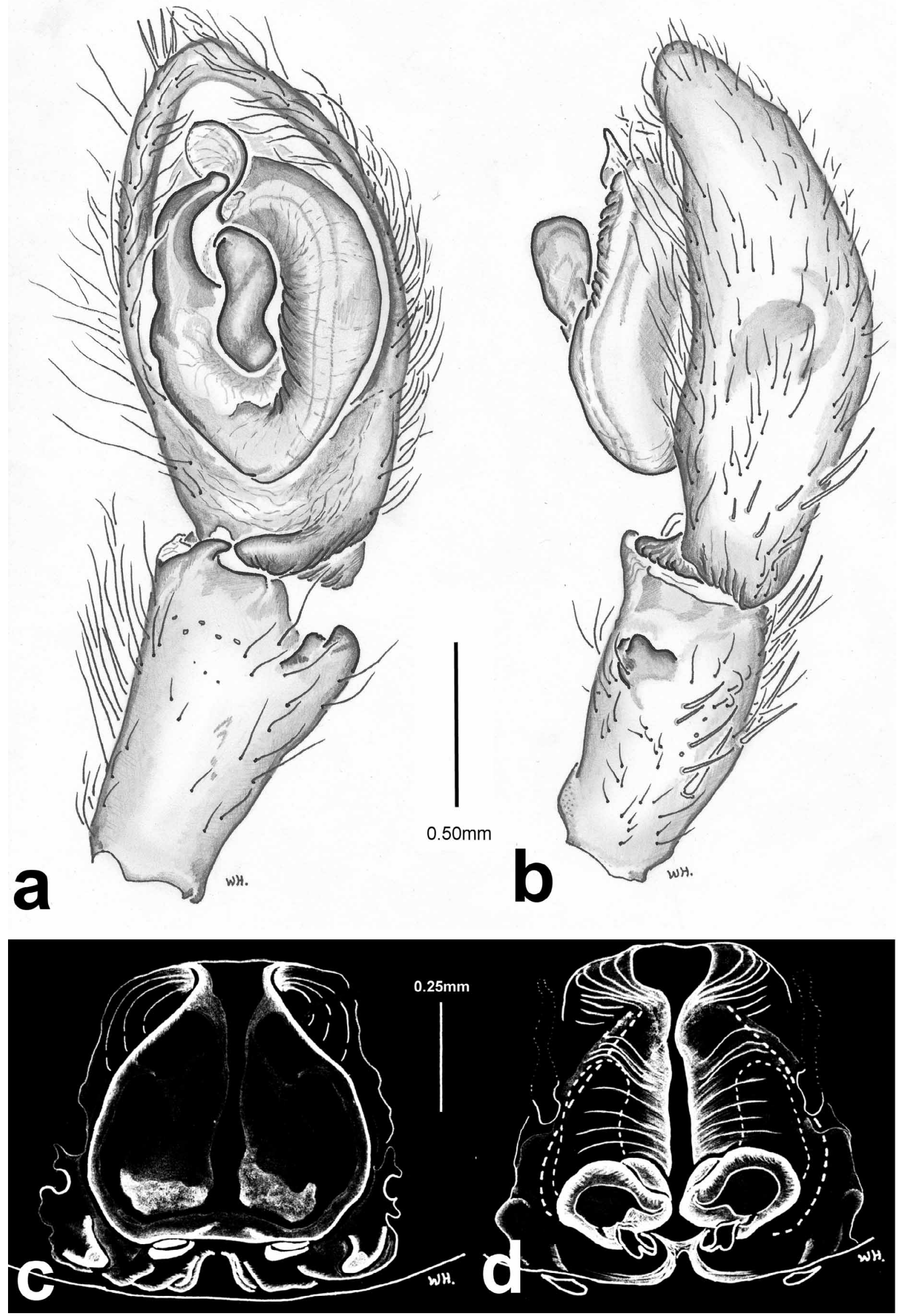

FIGURE 13. Austrotengella wrighti, sp. nov., male, palpal tibia, cymbium and bulb: ventral view (a) and retrolateral view (b). Scale line $=0.5 \mathrm{~mm}$. Allotype, female QMS28842: c, d. epigyne, external (c) and internal (d) views. 
Distribution and Habitat: Known only from rainforest at Mt French, southeastern Queensland and in northern New South Wales at Beaury State Forest.

\section{Acknowledgements}

This project began with assistance from an Australian Biological Resources Study (ABRS) grant to look at cursorial araneomorph spiders (1996-1998). During that grant and in the initial stages of the project Kylie Stumkat provided much support as did Mrs Helen Starcke to whom I am very grateful for wonderful rendition of Austrotengella wrighti (Figs. 12 a, b). Graham Milledge (AMS) kindly provided loans. Towards the closing stages, collection management support and excellent illustrations (Figures 2, 6, 7, 10-13) was provided by Wendy Hebron who is also given special thanks for her exceptional collection management skills and attention to detail. Comparative material of other tengellids was donated by Dr Norman I. Platnick, American Museum of Natural History, New York. Dr Barbara Baehr, Queeensland Museum, provided welcome support and company both in the field and the lab. Dr Chris Burwell provided provocative counterpoint in resolving issues of drivers of altitudinal movement. Martín Ramírez and an anonymous reviewer also made important contributions and criticisms, which are appreciated.

\section{References}

Barrow, W.M. (1940) New and rare spiders from the Great Smoky Mountain National Park region. Ohio Journal of Science, 40 , $130-138$.

Chen., I.C. , Shui, H.-J., Benedick, S., Holloway, J., Chey, V., Barlow, H., Hill, J. \& Thomas, C.D. (2009). Elevation increases in moth assemblages over 42 years on a tropical mountain. Proceedings of the National Academy of Science United States of America, 106, 75-82.

Dahl, F. (1908) Die Lycosiden oder Wolfsspinnen Deutschlands und ihre Stellung im Haushalt der Natur. Nach statistichen Untersuchungen dargestellt. Nova Acta Academiae Caesaerae Leopoldina-Carolinae Germanicae naturae curiosorum, $88,175-678$.

Davies, V. (1977) Spiders. In: Fauna of Eastern Australian Rainforests II. Queensland Museum, Brisbane, pp. 1-87, pls. 1-17.

Forster, R.R. (1955) A new family of spiders of the sub-order Hypochilomorphae. Pacific Science, 9, $277-285$.

Forster, R.R. \& Forster, L. (1999) Spiders of New Zealand and their Worldwide Kin. University of Otago Press, Dunedin, vii+270 pp.

Gray, M.R. \& Thompson, J. (2001) New lycosoid spiders from southern Australia and North West Cape Peninsula (Araneae: Lycosoidea). Records of the Western Australian Museum, Supplementary Series 64, 159-170.

Griswold, C.E. (1990) A revision and phylogenetic analysis of the spider subfamily Phylexidinae (Araneae, Amaurobiidae). Bulletin of the American Museum of Natural History, 196, 1-200.

Griswold, C.E. (1991) A revision and phylogenetic analysis of the spider genus Machadonia (Araneae, Lycosoidea). Entomologia scandanavica, 22, 305-351.

Griswold, C.E. (1993) Investigations into the phylogeny of the lycosoid spiders and their kin (Arachnida, Araneae, Lycosoidea). Smithsonian Contributions to Zoology, 539, 1-39.

Harvey, M.S. (2002) Short-range endemism among Australian fauna: some examples from non-marine environments. Invertebrate Systematics, 16, 555-570.

IPCC (Intergovernmental Panel on Climate Change) (2007) Contribution of Working Group I to the Fourth Assessment Report of the Intergovernmental Panel on Climate Change, 2007. Solomon, S., D. Qin, D., Manning, M., Chen, Z., Marquis, M., Avery, K.B., Tignor, M., \& Miller, H.L. (eds.) Cambridge University Press, Cambridge.

Janszen, D.H (1967) Why mountain passes are higher in the tropics. American Naturalist, 102, 323-249.

Kitching, R.L., Putland, D., Ashton, L.A., Laidlaw, M.J., Boulter, S.L., Christensen, H. \& Lambkin, C.L.. (2011). Detecting biodiversity changes along climatic gradients: the IBISCA -Queensland Project. Memoirs of the Queensland Museum, 55, 235-250.

Lenoir, J., Gegout, J-C., Guisan, A., Vittoz, P., Wohlgemuth, T., Zimmermann, N.E., Dullinger, S., Pauli, H., Willner, W. \& Svenning, J.C. (2010) Going against the flow: Potential mechanisms for unexpected downslope range shifts in a warming climate. Ecography, 33, 295-303.

Platnick, N.I. (1976) Concepts of dispersal in historical biogeography. Systematic Zoology, 25, 294-295.

Platnick, N.I. (1999) A revision of the Appalachian spider genus Liocranoides (Araneae: Tengellidae). American Museum Novitates, 3285, 1-13.

Platnick, N.I. \& Ubick, D. (2001) A revision of the North American spiders of the new genus Socalchemmis (Araneae, Tengellidae). American Museum Novitates, 3339, 1-25. 
Platnick, N.I. \& Ubick, D. (2005) A revision of the North American spider genus Anachemmis Chamberlin (Araneae, Tengellidae). American Museum Novitates, 3477, 1-20.

Platnick, N.I. \& Ubick, D. (2008) A revision of the endemic Californian spider genus Titiotus Simon (Araneae, Tengellidae). American Museum Novitates, 3608, 1-33.

Poloczanska, E.S., Smith, S., Fauconnet, L., Healy, J., Tibbetts, I.R., Burrows, M.T. \& Richardson, A.J. (2011) Little change in the distribution of rocky shore faunal communities on the Australian east coast after 50 years of rapid warming. Journal of Experimental Marine Biology and Ecology, 400, 145-154.

Raven, R.J., Baehr, B.C. \& Harvey, M.S. (2002) An Interactive key to Australian Spider Subfamilies. Australian Biological Resources Study: CSIRO Publishing, Melbourne.

Raven, R. J. \& Stumkat, K.S. (2005) Revisions of Australian ground-hunting spiders: II. Zoropsidae (Lycosoidea: Araneae). Memoirs of the Queensland Museum, 50, 347-423.

Raven, R.J., Stumkat, K. \& Gray, M.R. (2001) Revisions of Australian ground-hunting spiders: I. Amauropelma gen. nov. (Araneomorphae: Ctenidae). Records of the Western Australian Museum Supplementary series, 64, 187-227.

Silva, D. (2003) Higher-level relationships of the spider family Ctenidae (Araneae: Ctenoidea). Bulletin of the American Museum of Natural History, 274, 1-86.

Strong, C.L., Boulter, M.J., Laidlaw, S.L., Maunsell, S.C., Putland, D. \& Kitching, R.L. (2011). The physical environment of an altitudinal gradient in the rainforest of Lamington National Park, southeast Queensland. Memoirs of the Queensland Museum, 55, 251-270. 